\title{
Physicochemical and Medicinal Properties of Tualang, Gelam and Kelulut Honeys: A Comprehensive Review
}

\author{
Datu Agasi Mohd Kamal ${ }^{1,2}{ }^{10}$, Siti Fatimah Ibrahim ${ }^{1}$, Haziq Kamal ${ }^{1}$, Mohd Izhar Ariff Mohd Kashim ${ }^{3,4}$ \\ and Mohd Helmy Mokhtar 1,*(D) \\ 1 Department of Physiology, Faculty of Medicine, Universiti Kebangsaan Malaysia, \\ Kuala Lumpur 56000, Malaysia; datuagasi90@gmail.com (D.A.M.K.); timi@ukm.edu.my (S.F.I.); \\ kamalntee1@gmail.com (H.K.) \\ 2 Department of Biomedical Sciences and Therapeutics, Faculty of Medicine and Health Sciences, Universiti \\ Malaysia Sabah, Kota Kinabalu 88400, Malaysia \\ 3 Centre for Contemporary Fiqh and Sharia Compliance, Faculty of Islamic Studies, Universiti Kebangsaan \\ Malaysia, Bangi 43600, Malaysia; izhar.ukm@gmail.com \\ 4 Institute of Islam Hadhari, Universiti Kebangsaan Malaysia, Bangi 43600, Malaysia \\ * Correspondence: helmy@ukm.edu.my; Tel.: +60-3-9145-8619
}

Citation: Mohd Kamal, D.A.; Ibrahim, S.F.; Kamal, H.; Kashim, M.I.A.M.; Mokhtar, M.H

Physicochemical and Medicinal Properties of Tualang, Gelam and Kelulut Honeys: A Comprehensive Review. Nutrients 2021, 13, 197 https://doi.org/10.3390/nu13010197

Received: 15 December 2020 Accepted: 8 January 2021 Published: 10 January 2021

Publisher's Note: MDPI stays neutral with regard to jurisdictional clai$\mathrm{ms}$ in published maps and institutional affiliations.

Copyright: (C) 2021 by the authors. Licensee MDPI, Basel, Switzerland. This article is an open access article distributed under the terms and conditions of the Creative Commons Attribution (CC BY) license (https:// creativecommons.org/licenses/by/ $4.0 /)$.

\begin{abstract}
Tualang, Gelam and Kelulut honeys are tropical rainforest honeys reported to have various medicinal properties. Studies related to the medicinal properties and physicochemical characteristics of these honeys are growing extensively and receiving increased attention. This review incorporated and analysed the findings on the biological and physicochemical properties of these honeys. Tualang, Gelam and Kelulut honeys were found to possess a wide variety of biological effects attributed to their physicochemical characteristics. Findings revealed that these honeys have anti-diabetic, anti-obesity, anti-cancer, anti-oxidative, anti-microbial, anti-inflammatory and wound-healing properties and effects on the cardiovascular system, nervous system and reproductive system. The physicochemical properties of these honeys were compared and discussed and results showed that they have highquality contents and excellent antioxidant sources.
\end{abstract}

Keywords: Tualang honey; Gelam honey; Kelulut honey; health benefits; anti-oxidative; anti-cancer

\section{Introduction}

Honey has been utilised since ancient times due to its various health benefits. Despite medical advances achieved today, honey remains an integral part of a particular regional demographic. Owing to recent advancements in biotechnology, honey has been revealed to possess newly discovered unique contents and medicinal properties. Stingless bee honey, especially those from Malaysia, Australia, and Brazil, has been recently discovered as a novel source of trehalulose, a biologically active disaccharide with various health benefits [1]. A recent systematic review and meta-analysis showed that honey was superior to usual care for improving upper respiratory tract infections (URTIs). It was also more effective than antibiotics when prescribed to reduce the spread of anti-microbial resistance in URTIs [2]. Honey exhibited superior effects compared with conventional treatments for acute wounds, superficial partial-thickness burns and infected post-operative wounds [3,4]. Some honeys were licensed as a medical product and used in the clinical setting for wound care in Europe and Australia [5].

Tualang honey, Gelam honey and Kelulut honey are tropical rainforest honeys that mostly originated from Malaysia. The health benefits of these honeys have recently been gaining increased attention and popularity, as evidenced by numerous documented studies. Tualang honey is a wild polyfloral honey produced by Apis dorsata. This honey is named after one of the tallest tropical rainforest trees, the Koompassia excelsa tree (known locally as the Tualang tree), where bees build their hives. The bees collect nectar from plants in 
the tropical rain forest in the North-eastern region of Peninsular Malaysia in Kedah. This honey possesses anti-microbial, anti-cancer, antioxidant, and anti-inflammatory effects attributed to its high antioxidant contents [6,7]. Gelam honey is also wild honey produced by the A. dorsata bees, which build hives on trees locally called Gelam, or Melaleuca cajuputi Powell. Gelam honey is mostly obtained from the East Coast of Peninsular Malaysia in Terengganu state. This honey may delay the onset of chronic diseases and infections and regulate the optimal level of enzymatic activity in the body [8]. Kelulut honey is produced by Trigona spp., a stingless bee that gathers nectar from polyfloral sources [6,9]. This honey has a slightly sour taste and is more liquid than the other honeys. It possesses antibacterial, antioxidant, and anti-osteoporotic properties due to its high antioxidant properties $[10,11]$.

An updated study to comprehensively analyse the benefits of Tualang, Gelam and Kelulut honey is still required compared to other types of honey such as Manuka honey which has been extensively reviewed. With the recent growth in the body of literature for these kinds of honey, assessment of Tualang, Gelam, and Kelulut honeys is needed to avoid future cross-studies or unnecessary research due to missed reviews of the existing research. In this review, relevant studies related to the medicinal properties, health benefits and physicochemical properties of Tualang, Gelam, and Kelulut honeys were identified and critically analysed. The findings showed that most studies reported the health advantages of honey consumption, whereas some reported disadvantages or no significant changes upon consumption. Furthermore, analyses of physiochemical-related research revealed that Tualang, Gelam and Kelulut honeys have high-quality contents and excellent antioxidant sources.

\section{Methods of Review}

A literature search was undertaken to identify and map out relevant and pertinent articles related to the physicochemical and medicinal properties of Tualang, Gelam, and Kelulut honeys. Peer-reviewed and full-text English articles were gathered from a time frame as early as 1960 to May 2020 in electronic databases, including Scopus, MEDLINE via EBSCOhost, and Google Scholar. A literature search was performed by combining the following set of keywords: (1) Tualang or Kelulut or Gelam and (2) honey. The literature search was further supplemented by referencing related review articles and scientific reports found from the search results.

\section{Physicochemical Characteristics of Tualang, Gelam, and Kelulut Honeys}

Honey from different botanical and geographical origins has different physicochemical properties and compositions that ultimately affect their biological properties [8]. Numerous studies were conducted to investigate the physicochemical properties of Tualang, Gelam and Kelulut honeys. Twenty-two studies related to the physicochemical and content analyses on these selected honeys were found. These honeys have unique physicochemical properties mostly attributed to Malaysia's tropical climate. Table 1; Table 2 show the physicochemical characterisation of Tualang, Gelam and Kelulut honeys extracted from various studies. Considering Kelulut honey is a polyfloral honey, this review only included studies on Kelulut honey that mainly originated from the Acacia mangium trees to obtain a fair comparison.

On the one hand, Tualang and Gelam honeys mostly complied with the accepted range by the two most common legislation of honey criteria and standards referred to as the European Honey Legislation [12] and Codex Alimentarius Standards for Honey [13]. On the other hand, the Kelulut honey in various studies followed the Malaysian Standard Kelulut (Stingless Bee) [14]. According to the European Honey Legislation and the Codex Alimentarius Standards, honey moisture should be less than $20 \%$, with glucose and fructose composition of more than $60 \mathrm{~g} / 100 \mathrm{~g}$, sucrose content of not more than $5 \mathrm{~g} / 100 \mathrm{~g}$ and electrical conductivity of not more than $0.8 \mathrm{mS} / \mathrm{cm}$. According to the Malaysian Standard Kelulut, the raw honey moisture content from stingless bee must be less than $35 \mathrm{~g} / 100 \mathrm{~g}$, with a $\mathrm{pH}$ of less than 3.8 and 5-hydroxymethylfurfural of less than $30 \mathrm{mg} / \mathrm{kg}$. 
Most of the studies reported that Tualang and Gelam honeys contained more than $20 \%$ moisture content, thus violating European Honey Legislation and Codex Alimentarius Standards. Nonetheless, honey samples from tropical countries, such as Malaysia, typically have higher moisture content, which could be due to the rainy season all over the year [15]. Therefore, Malaysia's honey is always first treated by evaporation to reduce the water content, thereby simultaneously increasing the honey quality [16].

Meanwhile, the electrical conductivity of honey is used to determine the botanical origin and purity of honey [17]. An electrical conductivity of less than $0.8 \mathrm{mS} / \mathrm{cm}$ indicates blossom honey, whilst more than $0.8 \mathrm{mS} / \mathrm{cm}$ indicates honeydew honey [18]. According to the European Honey Legislation and the Codex Alimentarius Standards, honey's electrical conductivity should not be more than $0.8 \mathrm{mS} / \mathrm{cm}$. However, the Malaysian Standard Kelulut has not determined any range for an acceptable limit of electrical conductivity. The electrical conductivity of Tualang, Gelam and Kelulut honeys reported in this review is in a broad range of $0.74-1.51 \mathrm{mS} / \mathrm{cm}$. Various factors, such as storage, time, temperature, water content and concentration of ions and minerals, were reported to contribute to the electrical conductivity of honey [16].

Most bacteria grow in a neutral and mildly alkaline environment, whereas yeasts and moulds could grow in an acidic environment $(\mathrm{pH}=4.0-4.5)$. Conversely, the $\mathrm{pH}$ values of honey are neither those needed for bacteria nor yeast growth [15]. This is of great importance during storage, as they influence the texture, stability and shelf-life of honey [18]. The $\mathrm{pH}$ value of Tualang, Gelam, and Kelulut honeys were reported to be in the range of 3.14-3.83. Moreover, the sugar content of these three honeys has complied with the requirement of the European Honey Legislation and Codex Alimentarius Standards. In terms of honey colour characteristics, Tualang honey is described as light amber honey and Gelam honey belongs to dark amber honey, whilst standard Kelulut honey is amber brown $[15,19]$.

Many studies found that the antioxidant capacity of honey is strongly correlated with the concentration of its phenolic contents [20,21]. The phenolic content of honey comes from the plant that the bees feed on [22]. Thus, botanical origin plays a significant role in determining the constituents and antioxidant activity of honey [23]. Colour intensity is also associated with antioxidant properties. Numerous studies, including those on Gelam, Tualang and Kelulut honey, associated the honey colour intensity with antioxidant properties. Darker-coloured honey showed higher antioxidant activity and higher total phenolic content $[22,24-26]$. The present review also found that these three honeys have a high content of phenolic and flavonoid. Amongst the reviewed studies comparing the antioxidant properties of Tualang, Gelam and Kelulut honey, one study showed that Kelulut honey has the highest antioxidant properties in ranking after Manuka honey amongst Gelam and Tualang honeys [25]. By contrast, another study found Tualang honey to have higher antioxidant properties than Manuka, Kelulut, and Gelam honeys [27]. As mentioned earlier, the study also revealed higher free radical scavenging and antioxidant activity in Tualang honey than in Gelam and Borneo honeys [26].

The determination of trace elements in honey is essential for quality control and monitoring of trace element composition. High levels of trace elements could be dangerous and cause toxicity. The levels of trace elements in Tualang, Gelam and Kelulut honeys were within the permissible value set by the World Health Organization (WHO), and no honey contamination with pesticide residues was found [28]. 
Table 1. Physicochemical characteristics of Tualang, Gelam and Kelulut honeys.

\begin{tabular}{cccc}
\hline Physicochemical Characteristics & Tualang Honey & Gelam Honey & Kelulut Honey \\
\hline \multirow{2}{*}{ Colour characteristic (mm Pfund) } & $74.00-113.0$ & $122.00-139.0$ & 1.25 \\
& {$[15,16,29]$} & {$[15,16,30]$} & {$[31]$} \\
\hline \multirow{2}{*}{$\mathrm{pH}$} & $3.14-3.80$ & $3.38-3.83$ & $3.27-3.30$ \\
& {$[15,16,29,32]$} & {$[15,16,30,32]$} & {$[31,33]$} \\
\hline \multirow{2}{*}{ Moisture content } & $17.53-26.51 \%$ & $17.93-26.50 \%$ & $21.52-31 \%$ \\
& {$[15,16,29,32]$} & {$[15,16,30,32]$} & {$[31,33,34]$} \\
\hline \multirow{2}{*}{ Electrical conductivity, $(\mathrm{mS} / \mathrm{cm})$} & $0.75-1.37$ & $0.74-1.51$ & $0.33-0.69$ \\
\hline
\end{tabular}

Table 2. Chemical constituents of Tualang, Gelam and Kelulut honeys.

\begin{tabular}{|c|c|c|c|}
\hline Chemical Constituent & Tualang Honey & Gelam Honey & Kelulut Honey \\
\hline Total sugar content (g/100 g) & $\begin{array}{c}63.60-72.94 \\
{[29,32,36]}\end{array}$ & $\begin{array}{c}64.93-72.57 \\
{[30,32,36]}\end{array}$ & $65.83-71.65[31,33,34,36]$ \\
\hline Reducing sugar (g/100 g) & $\begin{array}{c}61.94 \\
{[29]}\end{array}$ & $\begin{array}{c}62.17 \pm 0.73 \\
{[30]}\end{array}$ & No report found \\
\hline Sucrose $(\mathrm{g} / 100 \mathrm{~g})$ & $\begin{array}{l}<0.01-1.66 \\
{[29,32,36]}\end{array}$ & $<0.01-2.77[30,32]$ & $<0.01-32.30[31,33,35,36]$ \\
\hline Glucose (g/100 g) & $\begin{array}{c}30.07-47.134 \\
{[32,36]}\end{array}$ & $32.85-50.447[32,36]$ & $9.22-23.44[31,33,35,36]$ \\
\hline Fructose (g/100 g) & $\begin{array}{c}41.732-44.56 \\
{[32,36]}\end{array}$ & $\begin{array}{c}44.908-44.74 \\
{[32,36]}\end{array}$ & $\begin{array}{c}15-22.05 \\
{[31,33,35,36]}\end{array}$ \\
\hline Maltose (g/100 g) & $\begin{array}{c}4.491 \\
{[32]}\end{array}$ & $\begin{array}{c}1.291 \\
{[32]}\end{array}$ & $\begin{array}{l}0-27.41 \\
{[31,33]}\end{array}$ \\
\hline Protein content $(\mathrm{g} / \mathrm{kg})$ & $\begin{array}{c}3.6-6.6 \\
{[29,32,36]}\end{array}$ & $3.14-7.0[30,32,36]$ & $\begin{array}{c}3.9-8.5 \\
{[33,34,36]}\end{array}$ \\
\hline Proline content (mg/kg) & $\begin{array}{c}248.53 \pm 1.33 \\
{[29]}\end{array}$ & $261.33 \pm 1.33[30]$ & No report found \\
\hline \multicolumn{4}{|l|}{ Mineral content (mg/kg) } \\
\hline Sodium & $\begin{array}{c}268.23-704.5 \\
{[28,36]}\end{array}$ & $\begin{array}{c}196.84-666.0 \\
{[28,36]}\end{array}$ & $\begin{array}{c}589.7 \\
{[36]}\end{array}$ \\
\hline Potassium & $\begin{array}{c}976.9-1576.40 \\
{[28,36]}\end{array}$ & $1132.2-1363.40[28,36]$ & $\begin{array}{c}732.2 \\
{[36]}\end{array}$ \\
\hline Calcium & $\begin{array}{c}76.4-165.10 \\
{[28,36]}\end{array}$ & $\begin{array}{c}177.9-275.77 \\
{[28,36]}\end{array}$ & $\begin{array}{c}191.9 \\
{[36]}\end{array}$ \\
\hline Iron & $\begin{array}{c}11.17-128.13 \\
{[28,36]}\end{array}$ & $\begin{array}{c}8.45-142.37 \\
{[28,36]}\end{array}$ & $\begin{array}{l}6.57 \\
{[36]}\end{array}$ \\
\hline Magnesium & $\begin{array}{c}35.03-71.04 \\
{[28,36]}\end{array}$ & $\begin{array}{c}31.63-49.38 \\
{[28,36]}\end{array}$ & $\begin{array}{c}33.81 \\
{[36]}\end{array}$ \\
\hline Zinc & $\begin{array}{c}2.28-13.20 \\
{[28,36]}\end{array}$ & $\begin{array}{c}1.45-29.23 \\
{[28,36]}\end{array}$ & $\begin{array}{c}2.162 \\
{[36]}\end{array}$ \\
\hline Arsenic & $\begin{array}{c}0.051-0.062 \\
{[28,36]}\end{array}$ & $\begin{array}{c}0.064-0.070 \\
{[28,36]}\end{array}$ & $\begin{array}{c}0.019 \\
{[36]}\end{array}$ \\
\hline Lead & $\begin{array}{l}0.183-0.231 \\
{[28,36]}\end{array}$ & $\begin{array}{c}0.145-0.777 \\
{[28,36]}\end{array}$ & $\begin{array}{c}0.154 \\
{[36]}\end{array}$ \\
\hline Cadmium & $\begin{array}{l}0-0.004 \\
{[28,36]}\end{array}$ & $\begin{array}{c}0.005-0.05 \\
{[28,36]}\end{array}$ & $\begin{array}{c}0.002 \\
{[36]}\end{array}$ \\
\hline Copper & $\begin{array}{c}1.25-2.144 \\
{[28,36]}\end{array}$ & $\begin{array}{c}2.089-2.21 \\
{[28,36]}\end{array}$ & $\begin{array}{c}1.776 \\
{[36]}\end{array}$ \\
\hline Cobalt & $\begin{array}{c}0.033 \pm 0.002 \\
{[28]}\end{array}$ & $\begin{array}{c}0.082 \pm 0.005 \\
{[28]}\end{array}$ & No report found \\
\hline $\begin{array}{l}\text { Total phenolic content } \mathrm{mg} / \mathrm{kg} \\
\text { (gallic acid) }\end{array}$ & $\begin{array}{c}251.7-1103.94 \\
{[16,21,29,37,38]}\end{array}$ & 606.17-1597.43 [16,21,38] & $477.30-614.7[31,33]$ \\
\hline Total flavonoid content & $\begin{array}{c}49.04-185.11 \text { (rutin) } \\
{[16,21]} \\
65.65 \text { (catechin) } \\
\text { [29] } \\
504.5 \text { (quercetin) } \\
\text { [38] }\end{array}$ & $\begin{array}{c}\text { 183.43-328.86 (rutin) } \\
\text { [16,21] } \\
461.1 \text { (quercetin) } \\
\text { [38] }\end{array}$ & $\begin{array}{c}36.3 \\
\text { (quercetin) }\end{array}$ \\
\hline
\end{tabular}




\section{Medicinal Properties of Tualang, Gelam and Kelulut Honeys}

In this section, the medicinal properties of Tualang, Gelam and Kelulut honeys are discussed in accordance with different properties. A total of 99 articles regarding the medicinal properties of Tualang, Gelam and Kelulut honeys were obtained, including 59 in vivo studies, 25 in vitro studies, 2 ex vivo, one study combine in-viva and invitro technique and 12 clinical trials involving humans. Among medicinal properties discussed below, all three honey shared these major health benefits; (a) anti-oxidative; (b) anti-cancer; (c) anti-inflammatory; (d) wound-healing; (e) anti-microbial; (f) anti-diabetic and; (g) anti-obesity (as seen in Figure 1).

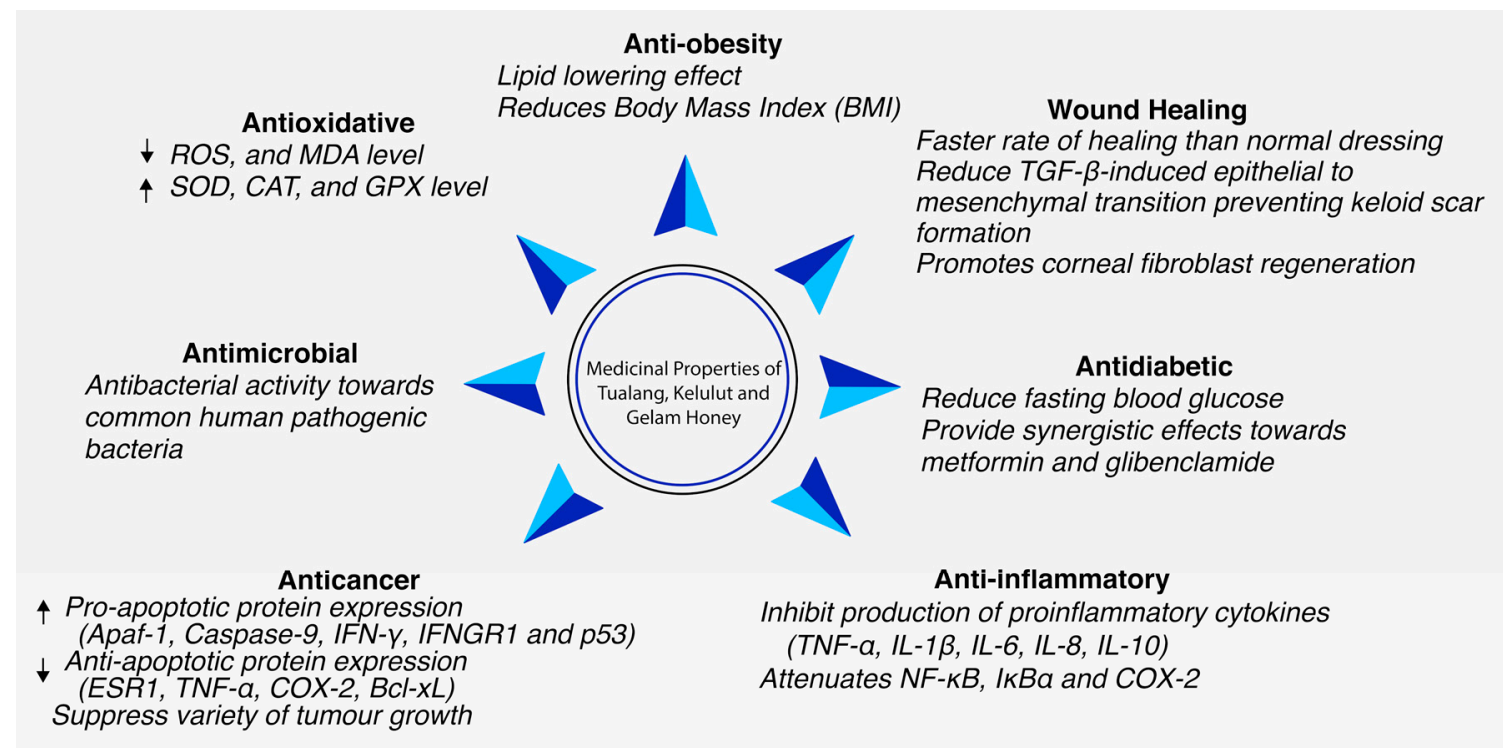

Figure 1. The medicinal properties of Tualang, Gelam and Kelulut honeys. ROS: reactive oxygen species; MDA: malondialdehyde; SOD: superoxide dismutase; CAT: catalase; GPX: glutathione peroxidase; TGF $\beta$ : transforming growth factor beta; Apaf-1: Apoptotic protease activating factor-1; IFN- $\gamma$ : interferon-gamma; IFNGR1: interferon gamma receptor-1; p53: tumor protein P53; ESR1: oestrogen receptor-1; TNF- $\alpha$ : tumor necrosis factor alpha; Bcl-xL: B-cell lymphoma-extra-large; IL-1 $\beta$ : interleukin-1 beta; IL-6: interleukin 6; IL-8: interleukin 8; IL-10: interleukin 10; NF-kB: nuclear factor kappa B; IkB $\alpha$ : NF-kappa-B inhibitor alpha; COX-2: cyclooxygenase-2.

\subsection{Anti-Oxidative Properties}

One of the most well-known benefits of honey is its anti-oxidative property. In this review, the most positive medicinal effects of Malaysian honey were attributed to its antioxidant properties. A plethora of studies regarding the antioxidative characteristic and pathways of Tualang, Gelam and Kelulut honeys are summarised and illustrated in Table 3 and Figure 2, respectively. Two studies reported that Gelam honey reduced oxidative damage by reducing DNA damage and the malondialdehyde (MDA) level of young, middle-aged and aged rats by modulating antioxidant enzyme activities [39,40]. Another study showed that the combination of Gelam honey and ginger provided a better antioxidant effect than Gelam honey or ginger alone, as evidenced by the significantly reduced superoxide dismutase (SOD) and catalase (CAT) activities, reduced MDA level, increased (reduced glutathione) GSH level and increased GSH/glutathione disulfide (GSSG) ratio in diabetic rats [41]. Another separate study reported the protective effect of Gelam honey on human diploid fibroblast (HDFs) exposed to gamma rays. Gamma irradiation to HDFs decreased SOD, CAT, and glutathione peroxidase (GPx) gene expression levels and enzyme activities, whilst treatment with Gelam honey increased both parameters [42]. 


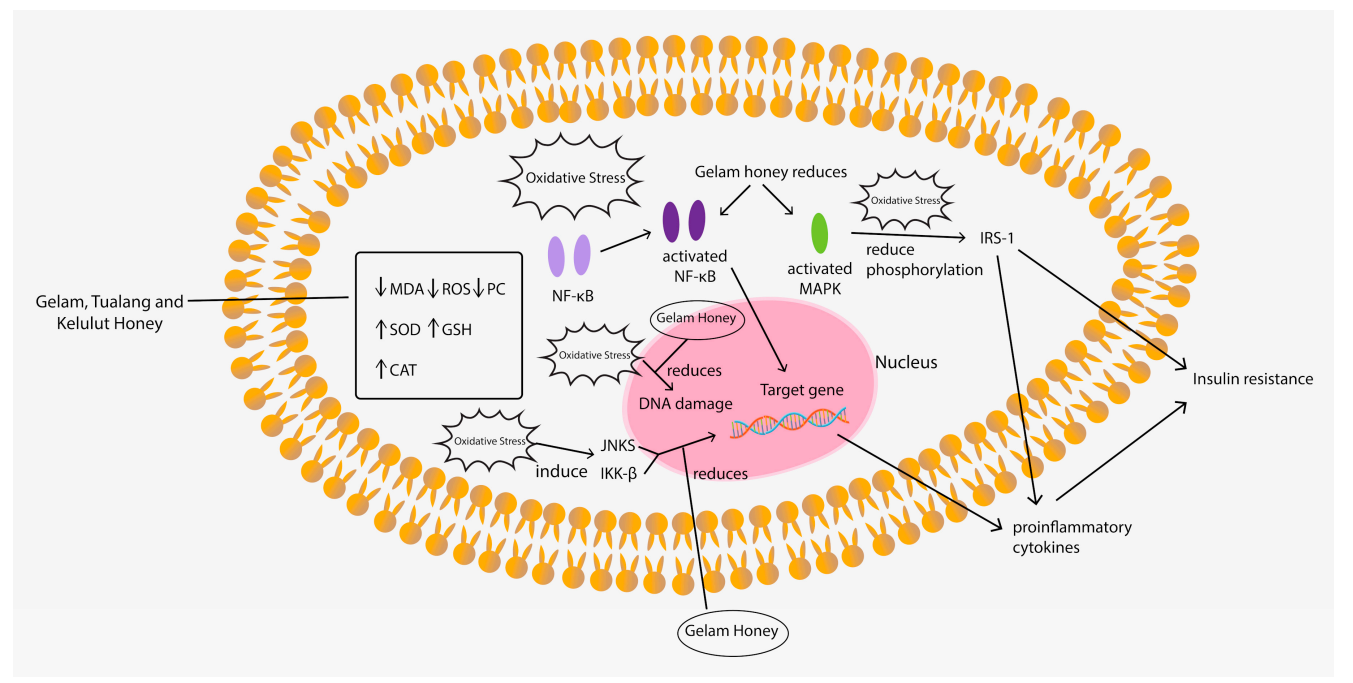

Figure 2. Anti-oxidative mechanism of Tualang, Gelam and Kelulut honeys. ROS: reactive oxygen species; MDA: malondialdehyde; SOD: superoxide dismutase; CAT: catalase; GSH: glutathione; PC: protein carbonyl; NF-kB: nuclear factor kappa B; MAPK: mitogen-activated protein kinases; JNKS: c-jun N-terminal kinases; IKK- $\beta$ : I-kappa-B-kinase beta; IRS-1: insulin receptor substrate-1.

In diabetes, oxidative stress interrupts glucose metabolism's normal coupling to insulin secretion by activating stress signaling nuclear factor- $\mathrm{kB}(\mathrm{NF}-\mathrm{kB})$ and $\mathrm{p} 38$ mitogenactivated protein kinase (MAPK) pathways. The activation of NF- $\mathrm{KB}$ causes the production of inflammatory cytokines that promote insulin resistance whilst activating MAPK to reduce insulin receptor substrate-1 (IRS-1) serine phosphorylation, thereby causing insulin resistance $[43,44]$. A series of studies have proven Gelam honey's protective effect on diabetes through this insulin resistance signaling pathway mechanism. Gelam honey exerts protective effects against diabetes and hyperglycemia-induced oxidative stress through improving insulin content and insulin resistance by producing the differential expression of insulin signaling pathways MAPK, NF- $\mathrm{kB}$, IRS-1 (ser307) and Akt in HIT-T15 cells [45]. Gelam honey had been shown to attenuate the oxidative stress-induced inflammatory pathways when pretreatment with Gelam honey or quercetin reduced the expression of phosphorylated jun-N-terminal kinase, IkappaB kinase and IRS-1, thereby significantly reducing the expression of proinflammatory cytokines, such as tumour necrosis factor alpha (TNF- $\alpha$ ), interleukin-6 (IL-6) and interleukin-1 $\beta$ (IL-1 $\beta$ ). A significant increase in phosphorylated Akt was also found, indicating the protective effects against inflammation and insulin resistance [46]. Batumalaie et al. (2014) reported that pretreatment of HIT-T15 cells with Gelam honey before culturing in hyperglycemic media yielded a significant decrease in the production of reactive oxygen species (ROS), glucose-induced lipid peroxidation and a significant increase in insulin content and the viability of cells cultured under hyperglycemic condition [47]. This series of studies demonstrated the potential antioxidative role of Gelam honey in managing diabetes through improving pathway-related insulin resistance and production.

Other studies have also explored the antioxidant capacity of Tualang honey. In animal study, Tualang honey was reported as having a hypoglycemic effect with reduced elevated MDA levels. It restored SOD and CAT activities in the pancreas of diabetic rats [48], suggesting the hypoglycemic effect of Tualang honey through its anti-oxidative effect on the pancreas. By contrast, another study using glibenclamide- and metformin-treated diabetic rats yielded no significant thiobarbituric acid reactive substances (TBARS) and CAT effects except that in GPx. However, the authors reported that a combination of glibenclamide, metformin and Tualang honey significantly up-regulated the CAT activity, down-regulated the GPx activity and reduced TBARS [49]. These findings suggested that Tualang honey potentiates the effect of glibenclamide and metformin to protect diabetic rat pancreas against oxidative stress and damage. Another study on diabetic rats revealed that 
Tualang honey ameliorated oxidative stress in kidneys of diabetic rats [50] and potentiated the effect of glibenclamide and metformin to protect diabetic rat kidneys against oxidative stress [51]. An in vitro study showed that Tualang honey improved human corneal epithelial progenitor cell migration and cellular resistance to $\mathrm{H}_{2} \mathrm{O}_{2}$-induced oxidative stress [52]. However, a study investigating the anti-inflammatory and antioxidant effects of Tualang honey in alkali injury on the eyes of rabbits did not find any significant difference between the Tualang honey-treated group and the group who underwent conventional treatment in terms of inflammatory feature and antioxidant status [53]. Consistent with the previous findings, Ahmad et al. (2017) reported the anti-oxidative properties of Tualang honey in a human study. The authors stated that consumption of 1.5 (high dose) and 0.75 (low dose) $\mathrm{g} / \mathrm{kg}$ of Tualang honey demonstrated a comparable response in increasing antioxidant activity (ferric reducing antioxidant power) and suppressing oxidative stress (MDA and ROS) in female athletes. The time-course effect of Tualang honey that provides optimal antioxidant activity and oxidative stress protection was between 1 and 2 hours after its consumption [54].

Table 3. Summary of anti-oxidative properties.

\begin{tabular}{|c|c|c|c|}
\hline Type of Honey & Type of Study & Findings & References \\
\hline Tualang honey & In vivo & $\begin{array}{l}\text { Tualang honey reduced elevated malondialdehyde (MDA) } \\
\text { levels and restored superoxide dismutase (SOD) and } \\
\text { catalase (CAT) activities in diabetic rats. }\end{array}$ & {$[48]$} \\
\hline Tualang honey & In vivo & $\begin{array}{l}\text { Tualang honey potentiated the effect of glibenclamide and } \\
\text { metformin to protect diabetic rat pancreas against } \\
\text { oxidative stress and damage. }\end{array}$ & [49] \\
\hline Tualang honey & In vivo & $\begin{array}{l}\text { Combination of Tualang honey with metformin or } \\
\text { glibenclamide provided additional antioxidant effect to } \\
\text { these drugs toward diabetic rat kidneys. }\end{array}$ & {$[51]$} \\
\hline Kelulut honey & In vivo & $\begin{array}{l}\text { Kelulut honey reduced oxidative stress by reducing lipid } \\
\text { peroxidation and increasing SOD. It also maintained bone } \\
\text { structure, increased osteoblast and reduced osteoclast } \\
\text { number in glucocorticoid-induced osteoporosis rat. }\end{array}$ & [11] \\
\hline Gelam honey & In vivo & $\begin{array}{l}\text { Gelam honey reduced oxidative damage in young and } \\
\text { middle-aged rats by modulating antioxidant } \\
\text { enzyme activities. }\end{array}$ & [39] \\
\hline Gelam honey & In vivo & $\begin{array}{l}\text { Gelam honey reduced oxidative damage in young and } \\
\text { aged rats through modulation of antioxidant } \\
\text { enzyme activities. }\end{array}$ & {$[40]$} \\
\hline Gelam honey & In vivo & $\begin{array}{l}\text { Combination of Gelam honey and ginger provided a better } \\
\text { antioxidant effect than Gelam honey or ginger alone, as } \\
\text { evidenced by significantly reduced SOD and CAT activities, } \\
\text { depleted MDA level, increased glutathione (GSH) level } \\
\text { and increased GSH/glutathione disulfide (GSSG) ratio in } \\
\text { diabetic rats. }\end{array}$ & {$[41]$} \\
\hline Gelam honey & In vitro & $\begin{array}{l}\text { Gelam honey and quercetin attenuated the oxidative } \\
\text { stress-induced inflammatory and insulin signalling } \\
\text { pathways in pancreatic hamster cells. }\end{array}$ & {$[46]$} \\
\hline Gelam honey & In vitro & $\begin{array}{l}\text { Gelam honey-induced differential expression of } \\
\text { mitogen-activated protein kinases (MAPK), nuclear factor } \\
\text { kappa B (NF-kB), insulin receptor substrate-1 (IRS-1) } \\
\text { (ser307), and Akt in HIT-T15 cells showed that Gelam } \\
\text { honey exerted protective effects against diabetes and } \\
\text { hyperglycaemia-induced oxidative stress by improving } \\
\text { insulin content and insulin resistance. }\end{array}$ & {$[45]$} \\
\hline
\end{tabular}


Table 3. Cont

\begin{tabular}{|c|c|c|c|}
\hline Type of Honey & Type of Study & Findings & References \\
\hline Tualang honey & In vitro & $\begin{array}{l}\text { Tualang honey possessed antioxidant properties and could } \\
\text { improve cell migration and cellular resistance to oxidative } \\
\text { stress in human corneal epithelial progenitor cells in vitro. }\end{array}$ & {$[52]$} \\
\hline Gelam honey & In vitro & $\begin{array}{l}\text { Gelam honey modulated the expression of antioxidant } \\
\text { enzymes at gene and protein levels in irradiated human } \\
\text { diploid fibroblasts, suggesting its potential as a } \\
\text { radioprotectant agent. }\end{array}$ & [42] \\
\hline Gelam honey & In vitro & $\begin{array}{l}\text { Pre-treatment of cells with Gelam honey extract or its } \\
\text { flavonoid components before culturing in hyperglycaemic } \\
\text { condition showed a significant decrease in reactive oxygen } \\
\text { species (ROS) production and glucose-induced lipid } \\
\text { peroxidation and a significant increase in insulin content } \\
\text { and the viability of pancreatic cells. }\end{array}$ & [47] \\
\hline Tualang honey & Human study & $\begin{array}{l}\text { Consumption of high }(1.5 \mathrm{~g} / \mathrm{kg}) \text { and low }(0.75 \mathrm{~g} / \mathrm{kg}) \text { doses } \\
\text { of Tualang honey demonstrated a comparable response in } \\
\text { increasing antioxidant activity and suppressing oxidative } \\
\text { stress in female athletes. The time-course effect of Tualang } \\
\text { honey that provided optimal antioxidant activity and } \\
\text { oxidative stress protection was between } 1 \text { and } 2 \text { hours after } \\
\text { its consumption. }\end{array}$ & [54] \\
\hline Tualang honey & In vivo & $\begin{array}{l}\text { No significant difference between Tualang honey treatment } \\
\text { and conventional treatment in terms of inflammatory } \\
\text { feature and antioxidant status in alkali injury on the } \\
\text { eyes of rabbits. }\end{array}$ & [53] \\
\hline
\end{tabular}

Kelulut honey has also been demonstrated to have anti-oxidative properties when it ameliorated glucocorticoid-induced osteoporosis via a reduction in lipid peroxidation and increase in SOD [11]. Kelulut honey supplementation prevented sperm and testicular oxidative damage in streptozotocin-induced diabetic rats by increasing SOD activity and GSH level and decreasing protein carbonyl (PC) and MDA levels in the sperm and testis [55].

The antioxidant properties of Gelam honey were well demonstrated by animal and in vitro studies discussed above. However, future works should explore the anti-oxidative effect of Gelam honey on humans. The antioxidant properties of honey have been attributed to its phytochemical content, which is phenolic and flavanoid. A study reported that the antioxidant activity of several types of honey originating from different countries depends on the concentration of phenolic and flavonoid groups [56]. These phenolic and flavonoids were reported to derive from the plant that the bees feed on [57]. The proposed honey antioxidant action mechanisms include free radical sequestration, hydrogen donation, metallic ion chelation, flavonoid substrate action for hydroxyl and superoxide radical actions [58].

\subsection{Anti-Cancer Properties}

Most of the literature on Tualang, Gelam, and Kelulut honeys focused on their anticancer properties in many models and various mechanisms. Studies involved all sets of subjects, from animal to cell culture and human studies. A total of 18 studies were found: five animal studies, 11 in vitro studies and two human studies. A summary of the anti-cancer properties for Tualang, Gelam, and Kelulut honey is provided in Table 4, while their anti-cancer pathway is illustrated in Figure 3.

Three in-vivo studies demonstrated the anti-cancer properties of Tualang honey in a breast cancer model [59-61]. The anti-cancer effect of Tualang honey was demonstrated through modulation in five aspects: tumor growth, tumor grading and haematologic, oestrogenic and apoptotic activities. Lower growth rate, tumor size, weight and multiplicity of tumor in the Tualang honey-treated group than those in the untreated control were reported in a rat breast cancer model [59-61]. Histologically, breast cancer rats treated with Tualang honey were primarily graded I and II compared with the untreated control, in which the majority was grade III $[59,60]$. Furthermore, Tualang honey increased the 
expression of proapoptotic proteins (Apaf-1, caspase-9, IFN- $\gamma$, IFNGR1, and p53) and decreased the expression of antiapoptotic proteins (ESR1, TNF- $\alpha$, COX-2 and Bcl-xL) [59,61]. Tualang honey treatment was also found to modulate haematological parameters, such as haemoglobin $(\mathrm{Hb})$, red blood cells (RBCs), packed cell volume (PCV), mean corpuscular volume (MCV), red cell distribution width (RDW), mean corpuscular hemoglobin concentration MCHC, polymorphs and lymphocytes values [59]. Manuka honey was reported to have the same anti-cancer properties as Tualang honey in an animal breast cancer model [61].

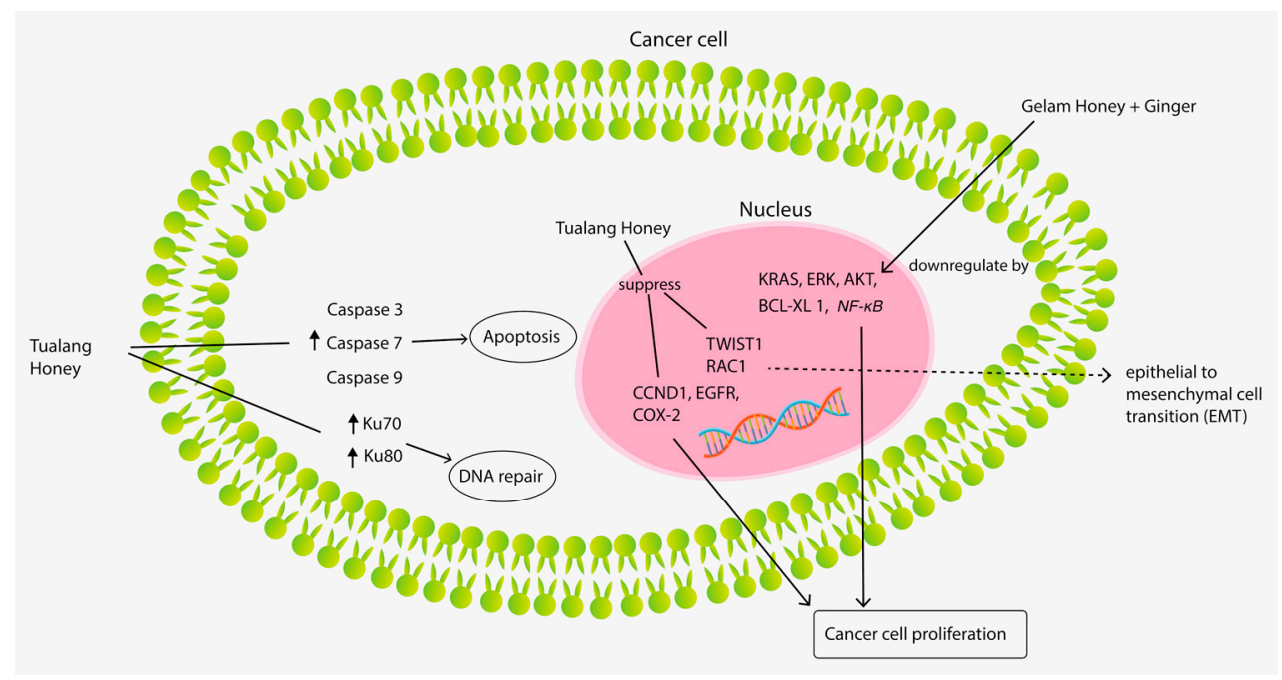

Figure 3. Anti-cancer mechanism of Tualang, Gelam and Kelulut honeys. KRAS: K-Ras encoding gene; ERK: extracellular signal-regulated kinase; AKT: protein kinase B; Bcl-xL: B-cell lymphoma-extra-large; NF-kB: nuclear factor kappa B; TWIST1: Twist-related protein 1 gene; RAC1: Ras-related C3 botulinum toxin substrate 1 gene; CCND1: Cyclin D1 gene; EGFR: epidermal growth factor receptor gene; COX-2: cyclooxygenase-2.

The anti-cancer effect of Tualang honey was successfully demonstrated in another three in vitro studies using the human breast cancer cell line [62-64]. These studies have shown that Tualang honey treatment-induced caspase-3, caspase-7 and caspase- 9 activation and decreased the mitochondrial membrane potential in all tested cancer cells, indicating that Tualang honey-induced apoptosis occurred least via a mitochondrial-dependent pathway $[62,63]$. Depolarisation of the mitochondrial membrane in breast cancer cell lines increased when Tualang honey was used in conjunction with tamoxifen compared with treatment with tamoxifen alone [63]. Interestingly, Tualang honey was found to be cytotoxic to breast cancer cell line (MCF-7); it also protected non-tumorigenic epithelial breast cell line (MCF-10A) from the toxic effects of tamoxifen active metabolite 4-hydroxytamoxifen by increasing the efficiency of the DNA repair mechanism in these cells, as evidenced by the increment in DNA repair proteins Ku70 and Ku80 [64]. Therefore, clinical trials may focus on Tualang honey as a possible adjuvant to be used with tamoxifen to minimise tamoxifen dosage and thus minimise the adverse effects. In a clinical trial, the combination of Tualang honey and anastrozole in decreasing breast background parenchymal enhancement in breast cancer patients was more successful than anastrozole alone [65]. Three-tier evidence from animal, in vitro and human studies demonstrated the benefit of Tualang honey in breast cancer, highlighting the potential use of Tualang honey as a natural supplement to chemotherapeutic agents used for breast cancer treatment.

In an animal model of oral squamous cell carcinoma, Tualang honey showed chemopreventive capabilities by suppressing cancer cell proliferation and activity, as demonstrated by the decrease in the expression of CCND1, EGFR, and COX-2, which are genes related to cancer development and cellular proliferation. In addition, Tualang honey inhibited the aggressiveness of oral squamous carcinoma by down-regulating TWIST1 and RAC1, which are the genes representing epithelial-to-mesenchymal transition (EMT), 
and overexpressing $\beta$-catenin and E-cadherin [66]. Meanwhile, another study proved that Tualang honey has an anti-proliferative effect on oral squamous cell carcinoma and osteosarcoma cell lines by inducing early apoptosis [67].

Other various anti-cancer potentials of Tualang honey have been discovered through in vitro studies, including anti-cancer activity against cervical cancer cell lines; this activity shares the same mechanism as in the in vitro study on breast cancer cell lines discussed above [62]. Man et al. (2018) reported the antileukemic effect of Tualang honey through its apoptosis-inducing ability for acute and chronic myeloid leukemia cell lines [68]. In another in vitro study, Tualang honey protected keratinocytes from ultraviolet radiation-induced inflammation and DNA damage by modulating the early biomarkers of photocarcinogenesis, thus providing significant protection from the adverse effects of ultraviolet B (UVB) radiation and a suggestion for its photochemopreventive potential [69]. A randomised clinical trial using Tualang honey has been conducted on cancer-related fatigue in patients with head and neck cancer. These patients received either $20 \mathrm{mg}$ of Tualang honey or $100 \mathrm{mg}$ of vitamin C tablet for 8 weeks, in which the level of fatigue and quality of life were measured using questionnaires with additional measurement of white cell count and C-reactive protein level. No significant changes were detected between the vitamin $\mathrm{C}$ and Tualang honey groups for the white cell count and C-reactive protein. However, the Tualang honey group showed a substantial improvement in fatigue and quality of life compared with the vitamin C group [70]. The author suggested that Tualang honey could be used as a supplement to improve the quality of life and reduce fatigue in patients with head and neck cancer.

Anti-cancer properties were also exhibited by Kelulut and Gelam honeys. A study by Yazan et al. (2017) showed that $1183 \mathrm{mg} / \mathrm{kg}$ of Kelulut honey treatment twice daily for 8 weeks significantly reduced the total number of aberrant crypt foci, aberrant crypts and crypt multiplicity in colorectal cancer-induced rats [71]. Several studies have demonstrated the anti-proliferative and apoptotic induction properties of Gelam honey on liver, colorectal and colon cancer cell lines [72-74]. A combination of Gelam honey and ginger produced synergism that provided an anti-cancer activity toward colon cancer cell through stimulation of early apoptosis (upregulation of caspase-9 and IкB genes) accompanied by downregulation of the expression of KRAS, extracellular signal-regulated kinase (ERK), protein kinase B (Akt), B-cell lymphoma-extra-large (Bcl-xL), and nuclear factor kappa B (NFkB) genes, which are related to cancer cell proliferation [75]. This combination also provided anti-cancer effects toward colorectal cancer by inhibiting mammalian target of rapamycin (mTOR) and Wnt $/ \beta$ catenin signaling pathways and the induction of apoptosis [76].

Table 4. Summary of anti-cancer properties.

\begin{tabular}{cll}
\hline Type of Honey & Type of Study & \multicolumn{1}{c}{ Findings } \\
\hline Kelulut honey & In vivo & $\begin{array}{l}\text { Kelulut honey possessed chemo-preventive properties in } \\
\text { rats induced with colorectal cancer and it was found to be } \\
\text { not toxic to rats. }\end{array}$ \\
\hline Tualang honey & $\begin{array}{l}\text { Tualang honey ameliorated breast cancer by increasing the } \\
\text { susceptibility of proapoptotic proteins; apoptotic protease } \\
\text { activating factor-1 (Apaf-1) interferon-gamma (IFN- } \gamma) \\
\text { interferon gamma receptor-1 (IFNGR1) tumor protein P53 } \\
\text { (p53) and decreased the expression of anti-apoptotic } \\
\text { proteins; tumour necrosis factor alpha (TNF- } \alpha), \\
\text { cyclooxygenase-2 (COX-2) and B-cell } \\
\text { lymphoma-extra-large (Bcl-xL). }\end{array}$ \\
\hline
\end{tabular}


Table 4. Cont

\begin{tabular}{|c|c|c|c|}
\hline Type of Honey & Type of Study & Findings & References \\
\hline Tualang honey & In vivo & $\begin{array}{l}\text { Tualang Honey alleviated breast cancers in rats by reducing } \\
\text { cancer cell growth and enhanced histological grading. }\end{array}$ & [60] \\
\hline Tualang honey & In vivo & $\begin{array}{l}\text { Tualang honey showed chemo-preventive properties in } \\
\text { oral squamous cell carcinoma-induced rats by suppressing } \\
\text { cancer cell proliferation and activity and preserving } \\
\text { cellular adhesion. }\end{array}$ & [66] \\
\hline Tualang honey & In vivo & $\begin{array}{l}\text { Tualang Honey alleviated breast carcinogenesis by } \\
\text { modulating haematologic, oestrogenic and apoptotic } \\
\text { activities in the breast cancer animal model. }\end{array}$ & [59] \\
\hline Tualang honey & In vitro & $\begin{array}{l}\text { Tualang honey promoted apoptotic cell death induced by } \\
\text { tamoxifen in breast cancer cell lines. }\end{array}$ & [63] \\
\hline Gelam honey & In vitro & $\begin{array}{l}\text { Gelam honey exhibited anti-proliferative activity and } \\
\text { apoptotic induction in liver cancer cell line. }\end{array}$ & [72] \\
\hline Tualang honey & In vitro & $\begin{array}{l}\text { Tualang honey showed an anti-proliferative effect on oral } \\
\text { squamous cell carcinoma and osteosarcoma cell lines by } \\
\text { inducing early apoptosis. }\end{array}$ & {$[67]$} \\
\hline Gelam honey & In vitro & $\begin{array}{l}\text { Gelam honey acted as a radioprotector against gamma } \\
\text { irradiation by attenuating radiation-induced cell death in } \\
\text { human diploid fibroblasts. }\end{array}$ & [77] \\
\hline $\begin{array}{l}\text { Gelam honey combine } \\
\text { with ginger }\end{array}$ & In vitro & $\begin{array}{l}\text { Combined treatment of Gelam honey and ginger extract } \\
\text { potentiated the anti-cancer effect of fluorouracil against } \\
\text { colorectal cancer cells. }\end{array}$ & {$[73]$} \\
\hline Gelam and Nenas honey & In vitro & $\begin{array}{l}\text { Gelam and Nenas honeys are capable of suppressing HT } 29 \\
\text { colon cancer cell growth by inducing apoptosis and } \\
\text { suppressing inflammation. }\end{array}$ & [78] \\
\hline Tualang honey & In vitro & $\begin{array}{l}\text { Tualang honey demonstrated cytotoxic and apoptotic } \\
\text { activities against human breast and cervical cancer cell } \\
\text { lines with the mitochondrial apoptotic } \\
\text { pathway's involvement. }\end{array}$ & [62] \\
\hline Gelam honey & In vitro & $\begin{array}{l}\text { Gelam honey showed a synergistic cytotoxic effect with } \\
\text { 5-fluorouracil against human adenocarcinoma colon cancer } \\
\text { HT-29 cells. }\end{array}$ & [74] \\
\hline $\begin{array}{l}\text { Gelam honey combined } \\
\text { with ginger }\end{array}$ & In vitro & $\begin{array}{l}\text { Combined treatment of ginger and Gelam honey was more } \\
\text { effective than treatments with either Gelam honey only or } \\
\text { ginger only in inhibiting the growth of HT29 colon cancer } \\
\text { cells by inducing early apoptosis, modulating the } \\
\text { expression of genes involved in the KRAS/ERK/ } \\
\text { PI3K/AKT pathways and suppressing inflammation via } \\
\text { the NFKB pathway. }\end{array}$ & [75] \\
\hline Tualang honey & In vitro & $\begin{array}{l}\text { Tualang honey demonstrated apoptosis-inducing ability } \\
\text { for acute and chronic myeloid leukaemia (K562 and } \\
\text { MV4-11) cell lines. }\end{array}$ & [68] \\
\hline Tualang honey & In vitro & $\begin{array}{l}\text { Tualang honey protected keratinocytes from ultraviolet } \\
\text { radiation-induced inflammation and DNA damage via } \\
\text { modulation in early biomarkers of photocarcinogenesis. }\end{array}$ & [69] \\
\hline Tualang honey & In vitro & $\begin{array}{l}\text { Tualang honey was found to be cytotoxic to breast cancer } \\
\text { cell line (MCF-7) but protected non-tumorigenic epithelial } \\
\text { breast cell line (MCF-10A) from the toxic effects of } \\
\text { tamoxifen active metabolite 4-hydroxytamoxifen. }\end{array}$ & [64] \\
\hline Tualang honey & Human study & $\begin{array}{l}\text { Tualang honey improved cancer-related fatigue and quality } \\
\text { of life of patients with head and neck cancer } \\
\text { post-chemotherapy or radiotherapy. }\end{array}$ & [70] \\
\hline Tualang honey & Human study & $\begin{array}{l}\text { Combination of Tualang honey and anastrozole showed } \\
\text { more improvement in decreasing breast background } \\
\text { parenchymal enhancement in patients with breast cancer } \\
\text { than anastrozole alone. }\end{array}$ & [65] \\
\hline
\end{tabular}

The combination of Gelam honey and ginger potentiated the anti-cancer effect of 5-fluorouracil against HCT 116 colorectal cancer cells by reducing proliferation and in- 
creasing apoptosis [73]. In a separate study, Gelam honey combined with 5-fluorouracil also provided a synergistic cytotoxic effect against human adenocarcinoma colon cancer HT-29 cells. The combined treatment showed a significantly higher cytotoxic effect and apoptosis induction on HT-29 cells than the stand-alone treatment with Gelam honey and 5-fluorouracil [74]. Another study showed that gamma irradiation up-regulated ATM, p53, p16 ${ }^{\text {ink4a }}$ and cyclin D1 genes and subsequently initiated cell cycle arrest at the G0/G1 phase and induced apoptosis. However, pre-treatment with Gelam honey caused downregulation of these genes in irradiated HDFs. Gelam honey treatment caused cells to progress to the $S$ phase with fewer cells in the G0/G1 phase, whilst apoptosis was inhibited [77]. This finding suggested the potential of Gelam honey as a radioprotector agent against gamma irradiation. Another study showed that Gelam honey inhibited the proliferation of HT 29 colon cancer cells by inducing DNA damage and apoptosis and suppressing inflammation [78]. In vitro studies have successfully revealed the anti-cancer properties of Gelam honey or in combination with ginger and their potentiating effect toward 5-fluorouracil. Thus, human studies using Gelam honey as a supplement to 5-fluorouracil should be conducted to prove the anti-cancer benefit of Gelam honey toward liver, colorectal and colon cancer cell lines as discussed above.

Honey generally contains various kinds of phytochemical with high phenolic and flavonoid content, thus contributing to its high antioxidant activity [79]. An agent with potent antioxidant properties could potentially prevent cancer, as free radicals induce oxidative stress, which causes cancer formation [80]. Moreover, a different type of polyphenol found in honey was reported to have anti-cancer properties against several types of cancer through various mechanisms. These polyphenols include caffeic acid, caffeic acid phenyl esters, chrysin, galangin, quercetin, kaempferol, acacetin, pinocembrin, pinobanksin and apigenin [81]. Honey is a natural immune booster, a natural anti-inflammatory agent, a natural anti-microbial agent, a natural promoter for chronic ulcers and wound healing and a natural antioxidant; these all serve as a basis for its anti-cancer properties.

\subsection{Anti-Microbial Properties}

The antibiotic resistance of bacteria is increasing nowadays; thus, the discovery of alternative antibacterial agents is urgently needed. Honey has been reported in numerous studies to possess anti-microbial activity. Although the anti-microbial activity of honey has been effectively established against an extensive spectrum of microorganisms, it differs depending on the type of honey. The anti-microbial activity of Tualang, Gelam, and Kelulut honeys has been documented in various studies. Table 5 provides a summarisation of the anti-microbial properties of these honeys. Tualang honey has been reported to possess antibacterial activity against Salmonella Typhi, Streptococcus pyogenes, Staphylococcus aureus, Staphylococcus epidermidis, Enterococcus faecium, Enterococcus faecalis, Escherichia coli, Salmonella enterica serovar Typhimurium, Klebsiella pneumoniae, and vancomycin-resistant enterococci $[82,83]$.

The antibacterial mechanism of honey is attributed to its high osmolarity, acidity and content of $\mathrm{H}_{2} \mathrm{O}_{2}$ and non-peroxide components [84]. $\mathrm{H}_{2} \mathrm{O}_{2}$ is derived from the hydrolysation of glucose-by-glucose oxidase, which could only occur when honey is diluted. $\mathrm{H}_{2} \mathrm{O}_{2}$ level is determined by relative glucose oxidase levels synthesised by the bee and catalase derived from floral [85]. In pure honey, high osmotic pressures and high acidity are responsible for the antibacterial properties of honey at this stage [84]. Some types of honey, such as Manuka honey, possess high non-peroxide antibacterial activity that could retain the antibacterial activity even after treatment with catalase [86]. They are known as active non-peroxide honey, containing various non-peroxide components that possess antibacterial actions [9]. These components include phenolic acids, flavonoids, methylglyoxal, and methyl syringate [84]. The antibacterial potencies of Tualang, Gelam, and Kelulut honeys were generally comparable to those of Manuka honey, with Tualang honey being the closest. Gelam, Kelulut, and Tualang honeys have a high antibacterial activity of total and non-peroxide activities, indicating that peroxide and non-peroxide components are 
mutually important antibacterial mechanism of these honeys [9]. Another study looked into the relationship between the phytochemicals and the antibacterial activity in wild honey of Sabah, Malaysia. Yap et al. (2012) found that anti-microbial activity was strongly positively correlated with the phenolic content, whilst the total flavonoid content was moderately positively correlated with antibacterial activity [87].

Gelam and Tualang honeys have been found to contain Lactobacillus acidophilus with anti-microbial activity against multiple antibiotic-resistant S. aureus, Staphylococcus epidermis and Bacillus subtilis. The anti-microbial compounds found were stable to heating, proteolytic enzyme treatment and $\mathrm{pH}$ adjustments [88]. This finding further strengthened the presence of anti-microbial properties in Tualang and Gelam honeys. A study comparing the anti-bacterial effects of topical gentamicin, topical Tualang honey and a combination of the two on pseudomonas-induced keratitis in rabbit eyes showed similar clinical and antimicrobial effects in all groups [89]. However, these results could not be verified because the study utilised a low sample size and no control group.

Two comparative studies on antibacterial potency revealed comparable results against Gram-negative bacteria tested with Aquacel-Manuka honey and Aquacel-Tualang honey dressing on the burn wound. However, for Gram-positive bacteria, Tualang honey was not as effective as the usual care products such as silver-based dressing or medical grade and Aquacel-Manuka honey dressings [90]. In another comparison study, Tualang honey showed equivalent or better activities than Manuka honey in some wound and enteric microorganisms, especially against Stenotrophomonas maltophilia and Acinetobacter baumannii [91]. Meanwhile, a study comparing the antibacterial potency amongst Gelam, Tualang and Durians honey showed that Gelam honey possessed the highest antibacterial effect [83].

Apart from its effective antibacterial property, honey possesses antifungal and antiviral properties. Tualang honey administration, especially at 40 and $60 \mathrm{~g}$ daily doses for 6 months in patients with asymptomatic human immunodeficiency virus (HIV), was shown to reduce viral load and improve their CD4 counts and quality of life [92]. Pediococcus acidilactici, a lactic acid bacteria strain, was isolated from Tualang honey and possessed antifungal activity against pathogenic Candida species [93].

The emergence of antibiotic-resistant bacteria has become a major problem among healthcare practitioners. Honey seems to be a promising alternative to solve this problem. As discussed in this section, Tualang and Gelam honeys were reported to be effective against a wide range of multi-resistant bacteria, indicating the possible utilisation of honey to combat antibiotic-resistant bacteria. Even though the current findings presented a strong case for honey's anti-microbial properties, future works should explore anti-microbial resistance toward honey and its side effects to be safely utilised as an alternative or to provide a synergistic effect with anti-microbial therapy [9,94].

Table 5. Summary of anti-microbial properties.

\begin{tabular}{|c|c|c|c|}
\hline Type of Honey & Type of Study & Findings & References \\
\hline Tualang honey & In vivo & $\begin{array}{l}\text { Topical gentamicin, topical Tualang honey and the } \\
\text { combination of the two all showed similar clinical and } \\
\text { anti-microbial effects in treating } \\
\text { Pseudomonas-induced keratitis in rabbits. }\end{array}$ & [89] \\
\hline $\begin{array}{l}\text { Tualang and } \\
\text { Gelam honey }\end{array}$ & In vitro & $\begin{array}{l}\text { Tualang and Gelam honeys showed antibacterial } \\
\text { activity against common human pathogenic bacteria, } \\
\text { namely Staphylococcus aureus, Staphylococcus epidermidis, } \\
\text { Enterococcus faecium, Enterococcus faecalis, Escherichia } \\
\text { coli, Salmonella enterica serovar Typhimurium and } \\
\text { Klebsiella pneumoniae, including vancomycin-resistant } \\
\text { enterococci, with Gelam honey showing the highest } \\
\text { antibacterial effect amongst the tested Malaysian } \\
\text { honey samples. }\end{array}$ & [83] \\
\hline Tualang honey & Human & $\begin{array}{l}\text { Tualang honey demonstrated bactericidal and } \\
\text { bacteriostatic effects for partial-thickness burn wounds. } \\
\text { It is useful as a dressing, as it is easier to apply and is } \\
\text { less sticky than Manuka honey. However, for } \\
\text { Gram-positive bacteria, Tualang honey is not as } \\
\text { effective as usual care products, such as silver-based } \\
\text { dressing or medical-grade honey dressing. }\end{array}$ & {$[90]$} \\
\hline
\end{tabular}


Table 5. Cont.

\begin{tabular}{|c|c|c|c|}
\hline Type of Honey & Type of Study & Findings & References \\
\hline Tualang honey & In vitro & $\begin{array}{l}\text { Pediococcus acidilactici, a lactic acid bacteria strain, was } \\
\text { isolated from Tualang honey; it possessed antifungal } \\
\text { activity against pathogenic candida species. }\end{array}$ & [93] \\
\hline $\begin{array}{l}\text { Gelam, Kelulut } \\
\text { and Tualang }\end{array}$ & In vitro & $\begin{array}{l}\text { Malaysian honey, namely Gelam, Kelulut, and Tualang, } \\
\text { exhibited high antibacterial potency derived from total } \\
\text { and non-peroxide activities, indicating that peroxide } \\
\text { and other constituents are mutually important as } \\
\text { contributing factors to the antibacterial } \\
\text { property of honey. }\end{array}$ & [9] \\
\hline Tualang honey & In vitro & $\begin{array}{l}\text { Tualang honey demonstrated variable activities against } \\
\text { different microorganisms but within the same range as } \\
\text { with Manuka honey. Tualang showed higher } \\
\text { antibacterial effect on A. baumannii and S. maltophilia. }\end{array}$ & [91] \\
\hline Tualang honey & In vitro & $\begin{array}{l}\text { Tualang honey showed antibacterial activity against } E \text {. } \\
\text { coli, } S \text {. typhi, and } S \text {. pyogenes, with the most potent } \\
\text { activity observed against } S \text {. typhi. However, it was } \\
\text { merely ineffective against } S \text {. sonnei, P. aeruginosa } \\
\text { and } S \text {. aureus. }\end{array}$ & [82] \\
\hline $\begin{array}{l}\text { Gelam and } \\
\text { Tualang honey }\end{array}$ & In vitro & $\begin{array}{l}\text { Gelam and Tualang honeys have been found to contain } \\
\text { Lactobacillus acidophilus, with anti-microbial activity } \\
\text { against multiple antibiotic-resistant } S \text {. aureus, } S \text {. } \\
\text { epidermis and Bacillus subtilis. The anti-microbial } \\
\text { compounds found were stable to heating, proteolytic } \\
\text { enzyme treatment and pH adjustments. }\end{array}$ & [88] \\
\hline Tualang honey & Human & $\begin{array}{l}\text { Tualang honey administration, especially at } 40 \text { and } 60 \\
\text { g daily doses for } 6 \text { months in asymptomatic patients } \\
\text { with human immunodeficiency virus (HIV), reduced } \\
\text { viral load and improved the CD } 4 \text { counts and quality of } \\
\text { life of these patients. }\end{array}$ & [92] \\
\hline
\end{tabular}

\subsection{Anti-Inflammatory Properties}

Tualang, Gelam, and Kelulut honeys demonstrated anti-inflammatory properties. Table 6 provides a summarisation of their anti-inflammatory properties and Figure 4 provides the pathway illustration. Gelam honey inhibited the production of proinflammatory mediators nitric oxide (NO), prostaglandin E2 (PGE2), TNF- $\alpha$ and IL-6 in carrageenaninduced acute paw oedema in rats. In this study, Gelam honey's anti-inflammatory effect was similar to that of the anti-inflammatory drug indomethacin [95]. Another study showed that Gelam honey inhibited NO and PGE2 in inflammatory tissues of carrageenaninduced acute paw oedema in rats. The author claimed the phenolic compounds in Gelam honey to be responsible for the anti-inflammatory effects [96]. A study by Hussein et al. (2013) demonstrated Gelam honey's inflammation inhibitory effects by attenuating NF- $\mathrm{kB}$ translocation to the nucleus and inhibiting IкB $\alpha$ degradation, which inhibits the production of proinflammatory mediators, including COX-2 and TNF- $\alpha$ [97]. Studies on the anti-inflammatory properties of Gelam honey were always consistent. For instance, the intravenous injection of Gelam honey inhibited lipopolysaccharide-induced endotoxemia in rats through the induction of heme oxygenase- 1 and the inhibition of cytokines (TNF- $\alpha$, IL-1 $\beta$ and IL-10), NO and high-mobility group protein B1 [98]. Besides, treatment with Gelam honey in lipopolysaccharide (LPS)-induced organ failure rat showed protective effects on organs by improving the organ blood parameters, reducing the infiltration of neutrophils and decreasing the myeloperoxidase activity and mortality compared with non-treatment. Thus, Gelam honey may have a therapeutic effect in protecting organs during inflammatory diseases [99]. Another mechanism for the anti-inflammatory properties of Gelam honey is through peroxynitrite synthesis inhibition during immune response in LPS-treated rats [100]. The anti-inflammatory properties of Gelam honey were further proven in two studies using asthma-induced mice and rabbits. Both studies reported that Gelam honey administration via oral gavage in mice and aerosolised Gelam honey in rabbits reduced airway inflammation by reducing the inflammatory cell [101,102]. Gelam 
honey-treated mice show similar improvement with the dexamethasone-treated group in terms of epithelium thickness, number of mast cells and mucus expression [101].

Tualang honey also demonstrated anti-inflammatory properties; pretreatment with Tualang honey reduced neuroinflammation by reducing the elevation of TNF- $\alpha$, IL- $1 \beta$, glial fibrillary acidic protein, allograft inflammatory factor 1 and COX- 2 in the rat cerebral cortex, cerebellum and brainstem in kainic acid (KA)-induced status epilepticus rat [103]. Another study also reported a reduction in TNF- $\alpha$, IL6 and IFN- $\gamma$ in the brain homogenates of a Tualang honey-treated chronic stress rat model [104]. However, the anti-inflammatory properties of Tualang honey could not be translated to humans as a randomised controlled study demonstrated that Tualang honey supplementation has opposite effects on TNF$\alpha$ and highly sensitive C-reactive protein, indicating the inconclusive effect of honey on inflammation amongst chronic smokers; thus, further studies are needed on other inflammatory markers or other study population [105]. Meanwhile, Kelulut honey has been reported to ameliorate the serum levels of CRP, TNF- $\alpha$, IL-1 $\beta$, IL- 6 , IL- 8 and MCP-1 in LPS-induced chronic subclinical systemic inflammation in rats by modulating NF- $\mathrm{kB}$, p38 MAPK and Nrf2 signaling [106].

Table 6. Summary of anti-inflammatory properties.

\begin{tabular}{|c|c|c|c|}
\hline Type of Honey & Type of Study & Findings & References \\
\hline Gelam honey & In vivo & $\begin{array}{l}\text { Gelam honey showed anti-inflammatory effects by reducing rat paw } \\
\text { oedema size and inhibiting the production of proinflammatory mediators } \\
\text { nitric oxide (NO), prostaglandin E2 (PGE2), tumor necrosis factor alpha } \\
\text { (TNF- } \alpha \text { ), and interleukin } 6 \text { (IL-6) in carrageenan-induced acute paw } \\
\text { oedema in rats. }\end{array}$ & {$[95]$} \\
\hline Gelam honey & In vivo & $\begin{array}{l}\text { Gelam honey and its extracts inhibited oedema, pain, NO and PGE(2) in } \\
\text { rats' paws induced with carrageenan in the non-immune inflammatory } \\
\text { and nociceptive model and lipopolysaccharide (LPS) in the } \\
\text { immune-inflammatory model. }\end{array}$ & [96] \\
\hline Gelam honey & In vivo & $\begin{array}{l}\text { Gelam honey exhibited its inflammation inhibitory effects in } \\
\text { carrageenan-induced rat paw inflammation by attenuating NF-kB } \\
\text { translocation to the nucleus and inhibiting IkBa degradation, with a } \\
\text { subsequent decrease in inflammatory mediators COX-2 and TNF- } \alpha \text {. }\end{array}$ & {$[97]$} \\
\hline Kelulut honey & In vivo & $\begin{array}{l}\text { Kelulut honey protected against LPS-induced chronic subclinical systemic } \\
\text { inflammation in rats mediated via amelioration of inflammation, } \\
\text { oxidative stress and NF-kB, p38 MAPK and Nrf2 signalling. }\end{array}$ & [106] \\
\hline Tualang honey & In vivo & $\begin{array}{l}\text { Tualang honey treatment reduced TNF- } \alpha \text {, IL } 6 \text { and IFN- } \gamma \text { in brain } \\
\text { homogenates of a chronic stress rat model. }\end{array}$ & [104] \\
\hline Tualang honey & In vivo & $\begin{array}{l}\text { Pre-treatment with Tualang honey reduced neuroinflammation by } \\
\text { reducing the elevation of TNF- } \alpha \text {, IL- } 1 \beta \text {, glial fibrillary acidic protein, } \\
\text { allograft inflammatory factor } 1 \text { and COX- } 2 \text { in the cerebral cortex, } \\
\text { cerebellum and brainstem of kainic acid-induced status epilepticus rat. }\end{array}$ & [103] \\
\hline Gelam honey & In vivo & $\begin{array}{l}\text { Gelam honey alleviated the histopathological changes in a mouse model } \\
\text { of allergic asthma. }\end{array}$ & [101] \\
\hline Gelam honey & In vivo & $\begin{array}{l}\text { Treatment with aerosolised Gelam honey reduced the number of airway } \\
\text { inflammatory cells present in bronchoalveolar lavage fluid and inhibited } \\
\text { goblet cell hyperplasia in a rabbit model of ovalbumin-induced } \\
\text { chronic asthma. }\end{array}$ & [102] \\
\hline Tualang honey & Human study & $\begin{array}{l}\text { Tualang honey supplementation exhibited opposite effects on TNF- } \alpha \text { and } \\
\text { highly sensitive C-reactive protein amongst chronic smokers. }\end{array}$ & [105] \\
\hline Gelam honey & In vivo & $\begin{array}{l}\text { Gelam honey inhibited lipopolysaccharide-induced endotoxemia in rats } \\
\text { through the induction of heme oxygenase- } 1 \text { and the inhibition of } \\
\text { cytokines, nitric oxide and high-mobility group protein B1. }\end{array}$ & [98] \\
\hline Gelam honey & In vivo & $\begin{array}{l}\text { LPS-induced organ failure rats treated with Gelam honey demonstrated } \\
\text { protection on organs through improved organ blood parameters, reduced } \\
\text { infiltration of neutrophils, decreased myeloperoxidase activity and } \\
\text { reduced mortality compared with untreated rabbits. }\end{array}$ & [99] \\
\hline Gelam honey & In vivo & $\begin{array}{l}\text { Gelam honey showed anti-inflammatory properties through peroxynitrite } \\
\text { synthesis inhibition during immune response in LPS-treated rats. }\end{array}$ & {$[100]$} \\
\hline
\end{tabular}




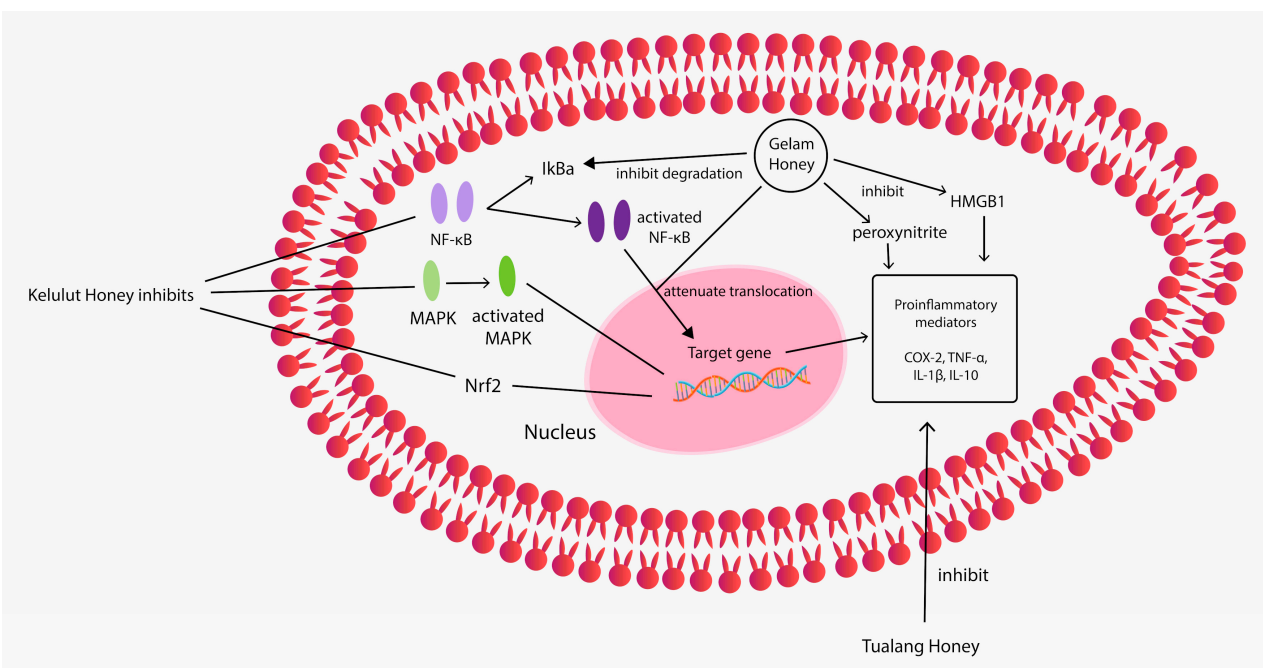

Figure 4. Anti-inflammatory mechanism of Tualang, Gelam and Kelulut honeys. TNF- $\alpha$ : tumor necrosis factor alpha; COX-2: cyclooxygenase-2; TNF- $\alpha$ : tumour necrosis factor alpha; IL-1 $\beta$ : interleukin-1 beta; IL-10: interleukin 10; NF-kB: nuclear factor kappa B; IкB $\alpha$ : NF-kappa-B inhibitor alpha; MAPK: mitogen-activated protein kinases; Nrf2: nuclear factor erythroid 2-related factor 2.

\subsection{Anti-Diabetic Properties}

Only Tualang and Kelulut honeys were found to have an anti-diabetic effect in three animal studies $[50,107,108]$ and two human studies $[109,110]$, as summarised in Table 7 . Studies using a diabetic model of rat showed that Tualang honey possessed moderate hypoglycaemic effect [50], improved liver enzyme profile [107], and possessed a synergetic benefit on glycaemic and metabolic profiles when administered together with metformin or glibenclamide [108].

Tualang honey was found to have intermediary glycemic index values of $65 \pm 7$ [110]. Hussain et al. (2012) reported that supplementation of $20 \mathrm{~g} /$ day Tualang honey for 4 months in healthy postmenopausal women caused a significant increase in fasting blood sugar (FBS) [111]. However, by prolonging the treatment to 12 months, a decrease in FBS levels was reported in healthy and diabetic postmenopausal women [112]. Wahab et al. (2018) suggested a differential effect of honey on glucose metabolism for short- and long-term use. [112]. Recent findings by Rashid et al. (2019) supported a prior claim that the ingestion of Kelulut honey daily for 30 days has no significant effect on fasting glucose and fasting lipid profile in patients with impaired fasting blood glucose [109]. The authors suggested short-duration ingestion of Kelulut honey as the factor for the insignificant result. By contrast, one in vivo study showed that supplementation of Kelulut honey for the last 35 days in a 16-week high-carbohydrate high-fructose diet fed in rats decreased the fasting blood glucose compared with non-supplemented control [113]. However, the effect of Tualang honey as an anti-diabetic is unclear. Future studies should extend knowledge on the anti-diabetic properties of Tualang honey on patients with diabetes to reinforce the anti-diabetic ability of Tualang honey, as the animal studies discussed above $[50,107,108]$ have successfully proven that Tualang honey possesses anti-diabetic effect in animals.

Although the anti-diabetic effect of honey may sound paradoxical as it contains a high content of sugar, several studies proved it otherwise. The honey from Nigeria has been reported to have an anti-hyperglycaemic effect in diabetic rats [114]. Moreover, the honey from Iran was reported to cause a mild reduction in FBS by $4.2 \%$ among overweight adults [115]. The fructose, oligosaccharides, antioxidants and trace minerals present in honey may contribute to its glucose-lowering effect [114]. Disaccharide trehalulose has been recently revealed as the main component of Kelulut honey with a low insulinemic and glycaemic index [1]. However, contradictory results of anti-diabetic properties of honey were also reported, as the honey from Iran increased the HbA1c level after 8 weeks 
of honey supplementation amongst patients with type 2 diabetes [116]. Thus, studies to discover the relation between honey and glucose metabolism in humans are needed to enlighten the natural characteristic of honey, whether it is beneficial or contraindicated in patients with diabetes.

Table 7. Summary of anti-diabetic properties.

\begin{tabular}{|c|c|c|c|}
\hline Type of Honey & Type of Study & Findings & References \\
\hline Tualang honey & In vivo & $\begin{array}{l}\text { Tualang honey produced a moderate hypoglycaemic effect and } \\
\text { ameliorated oxidative stress in the kidneys of streptozotocin-induced } \\
\text { diabetic rats. }\end{array}$ & {$[50]$} \\
\hline Tualang honey & In vivo & $\begin{array}{l}\text { Tualang honey demonstrated hepatoprotective effect in diabetic rats } \\
\text { by reducing aspartate aminotransferase (AST), alanine } \\
\text { aminotransferase (ALT) and alkaline phosphatase (ALP) activities. }\end{array}$ & [107] \\
\hline Tualang honey & In vivo & $\begin{array}{l}\text { Combination of glibenclamide or metformin with Tualang honey } \\
\text { improved glycaemic control and provided additional metabolic } \\
\text { benefits not achieved with either glibenclamide or metformin alone. }\end{array}$ & {$[108]$} \\
\hline Kelulut honey & Human study & $\begin{array}{l}\text { Thirty g of Kelulut honey daily intake for } 30 \text { days caused no changes } \\
\text { in fasting glucose, fasting lipid profiles, body mass index (BMI), waist } \\
\text { circumference, blood pressure, total cholesterol, triglyceride, } \\
\text { high-density lipoprotein (HDL) and low-density lipoprotein (LDL) in } \\
\text { patients with impaired fasting glucose. }\end{array}$ & [109] \\
\hline Tualang honey & Human study & Tualang honey is an intermediate glycaemic index food (GI = $65 \pm 7)$. & [110] \\
\hline
\end{tabular}

\subsection{Anti-Obesity Properties}

Only Gelam and Kelulut honeys have been found to show anti-obesity properties in animal studies [117-119], as provided in Table 8. Supplementation of Kelulut honey yielded a higher reduction in body mass index (BMI), the percentage of body weight gain, adiposity index, and relative organ weight in a high-fat diet-induced obese rat model than that of orlistat, an anti-obesity drug [117]. Meanwhile, another study has shown that Kelulut honey could prevent changes, such as high omental fat mass, serum triglyceride, systolic blood pressure, diastolic blood pressures, adipocyte area and adipocyte perimeter, caused by metabolic syndrome-induced rats [119].

Gelam honey has been shown to possess lipid-lowering and anti-oxidative capabilities in obesity-induced rats and weight-reducing ability compared with Acacia honey. However, honey showed better effects than orlistat, as the orlistat group showed hepatotoxicity effects [118].

A study conducted by Iranian researchers found that honey supplementation in humans also reduced body weight, body fat and total cholesterol [115]. As of now, Tualang honey has not been demonstrated to have an anti-obesity effect. Meanwhile, Gelam and Kelulut honeys have not been explored for their anti-obesity potential in humans.

Table 8. Summary of anti-obesity properties.

\begin{tabular}{ccl}
\hline Type of Honey & Type of Study & \multicolumn{1}{c}{ Findings } \\
\hline Kelulut honey & In vivo & $\begin{array}{l}\text { Kelulut honey treatment showed improved BMI, percentage of body } \\
\text { weight gain, adiposity index, relative organ weight, LDL, HDL and } \\
\text { hepatoprotective effect in high-fat diet-induced obese rats. }\end{array}$ \\
\hline Gelam honey & In vivo & $\begin{array}{l}\text { Reductions in excess weight gain, adiposity index levels, plasma glucose, } \\
\text { triglycerides, cholesterol, plasma leptin and resistin, liver enzymes, renal } \\
\text { function test and relative organ weight were found in Gelam } \\
\text { honey-treated groups compared with rats fed with the high-fat diet. }\end{array}$ \\
\hline Kelulut honey & In vivo & $\begin{array}{l}\text { Kelulut honey supplementation significantly prevented changes in } \\
\text { omental fat mass, serum triglyceride, systolic blood pressure, diastolic } \\
\text { blood pressures, adipocyte area and adipocyte perimeter induced by } \\
\text { high-carbohydrate and high-fat diet in rat. }\end{array}$ \\
\hline
\end{tabular}




\subsection{Wound-Healing Properties}

Honey has been used to treat wounds beginning from ancient times [120]. This practice was rooted primarily in tradition and folklore when investigators began to explore its medicinal potential [121]. The honey from different geographical areas has been reported to have considerable therapeutic effects on chronic wounds, ulcers and burns [122]. A study reported that honey has almost equal or slightly superior effects compared with conventional treatments for acute wounds and superficial partial-thickness burns [3]. Tualang, Gelam and Kelulut honeys have been demonstrated to have wound-healing properties, as listed in Table 9. Their wound-healing mechanism is provided in Figure 5.

In two studies, Tualang honey was compared with hydrofibre, hydrofibre silver or chitosan gel on full-thickness burn wounds in rats inoculated with Pseudomonas aeruginosa, K. pneumoniae or Acinetobacter baumannii. The first study by Khoo et al. (2010) found that the Tualang honey-treated group had more improved wound contraction and control over P. aeruginosa growth than the hydrofibre- and hydrofibre silver-treated groups [123]. A study by Sukur et al. (2011) showed that topical application of Tualang honey on burn wounds contaminated with P. aeruginosa and A. baumannii provided a faster healing rate than chitosan gel or hydrofibre silver treatment [124]. Meanwhile, another study showed that the oral treatment of Tualang honey enhanced anastomotic wound healing in large bowel anastomosis in rats by increasing the number of fibroblasts and decreasing inflammatory cells, leading to increased wound strength [125]. A clinical trial looking into Tualang honey's effect on promoting the post-tonsillectomy healing process has been conducted by comparing sultamicillin-treated group and sultamicillin + Tualang honeytreated group. Tualang honey was topically administered intraoperatively and $4 \mathrm{ml}$ orally three times daily for 7 days after surgery. The results obtained showed that the healing process was much faster in the Tualang honey + sultamicillin-treated group [126]. The multiple studies discussed above found Tualang honey to yield better wound-healing improvement than the current antibiotic or topical treatment, which could suggest the use of Tualang honey as a wound dressing.

Gelam honey has also been demonstrated to have wound-healing properties. A study reported that Gelam honey-dressed wounds healed faster with less scab and only thin scar formations than the untreated, saline-treated and intrasite gel-treated full-thickness excisional wounds in rats [127]. Zohdi et al. (2012) developed a Gelam honey-based hydrogel. They found that the application of Gelam honey hydrogel dressings significantly increased wound closure and accelerated the rate of re-epithelialisation compared with control hydrogel and OpSite film dressing in deep partial-thickness burn wounds in rats [128]. The application of Gelam honey-based hydrogel decreased the inflammatory response as seen by the suppressed expression of proinflammatory cytokines IL- $1 \alpha$, IL-1 $\beta$ and IL-6 [128]. In another study, Gelam honey was shown to promote in vitro corneal fibroblast wound healing, where corneal fibroblast cultured with Gelam honey demonstrated faster wound closure than the control group [129]. Moreover, two studies have shown that Gelam honey at a concentration of $0.0015 \%$ promoted ex-vivo corneal keratocytes and corneal epithelial cell proliferation whilst preserving their phenotypical features $[130,131]$. These findings could suggest Gelam honey formulation gel for topical treatment in wound healing for humans.

Wound healing is associated with keloid scar formation. Keloid scar formation is due to the excessive induction of EMT by TGF $\beta$ in keratinocytes. In a study, treatment of $0.0015 \%$ Kelulut honey has been demonstrated to reduce the TGF $\beta$-induced EMT in human primary keratinocytes, indicating Kelulut honey's therapeutic potential in preventing keloid scar formation [132]. Rats pretreated with Kelulut honey showed significantly reduced total area of ulcer and ulcer index compared with an untreated ethanol-induced gastric ulcer rat [133]. Honey is generally reported to have remarkable effects compared with conventional treatments for acute wounds, superficial partial-thickness burns and infected post-operative wounds $[3,4]$. 
Table 9. Summary of wound-healing properties.

\begin{tabular}{|c|c|c|c|}
\hline Type of Honey & Type of Study & Findings & References \\
\hline Gelam honey & In vivo & $\begin{array}{l}\text { Application of Gelam honey hydrogel dressings enhanced wound } \\
\text { closure and accelerated the rate of re-epithelialisation, with a } \\
\text { significant decrease in inflammatory response and expression of } \\
\text { proinflammatory cytokines (IL- } 1 \alpha \text {, IL-1 } \beta \text { and IL-6). }\end{array}$ & [128] \\
\hline Tualang honey & In vivo & $\begin{array}{l}\text { Tualang honey demonstrated enhanced control of Pseudomonas } \\
\text { aeruginosa and wound contraction effects on full-thickness burn } \\
\text { wound in vivo. }\end{array}$ & [123] \\
\hline Gelam honey & In vivo & $\begin{array}{l}\text { Gelam honey dressing on excisional wounds accelerated the process } \\
\text { of wound healing, with less scab and only thin scar formations. }\end{array}$ & [127] \\
\hline Gelam honey & Ex vivo & $\begin{array}{l}\text { Gelam honey }(0.0015 \%) \text { promoted ex-vivo corneal keratocyte } \\
\text { proliferation whilst preserving phenotypical features. }\end{array}$ & [130] \\
\hline Gelam honey & Ex vivo & $\begin{array}{l}\text { Gelam honey promoted the proliferative phase of corneal } \\
\text { reepithelialisation whilst preserving phenotypical features. }\end{array}$ & [131] \\
\hline Gelam honey & In vitro & Gelam honey promoted ex-vivo corneal fibroblast wound healing. & [129] \\
\hline Tualang honey & in vivo & $\begin{array}{l}\text { Topical application of Tualang honey on full-thickness burn wounds } \\
\text { contaminated with } P \text {. aeruginosa and A. baumannii provided the fastest } \\
\text { rate of healing amongst Chitosan gel or hydrofibre silver treatments. }\end{array}$ & [124] \\
\hline Tualang honey & In vivo & $\begin{array}{l}\text { Oral treatment with Tualang honey enhanced anastomotic wound } \\
\text { healing by increasing the number of fibroblasts and decreasing } \\
\text { inflammatory cells, leading to increased wound strength. }\end{array}$ & [125] \\
\hline Kelulut honey & In vivo & $\begin{array}{l}\text { Rats pre-treated with Kelulut honey showed significantly reduced } \\
\text { total area of ulcer and ulcer index compared with untreated } \\
\text { ethanol-induced gastric ulcer rats. }\end{array}$ & [133] \\
\hline Kelulut honey & In vitro & $\begin{array}{l}\text { Kelulut honey }(0.0015 \%) \text { reduced TGF } \beta \text {-induced EMT in human } \\
\text { primary keratinocytes, indicating its therapeutic potential in } \\
\text { preventing keloid scar formation. }\end{array}$ & [132] \\
\hline Tualang honey & Human & $\begin{array}{l}\text { Tualang honey enhanced the healing process in patients who } \\
\text { underwent tonsillectomy. }\end{array}$ & [126] \\
\hline
\end{tabular}

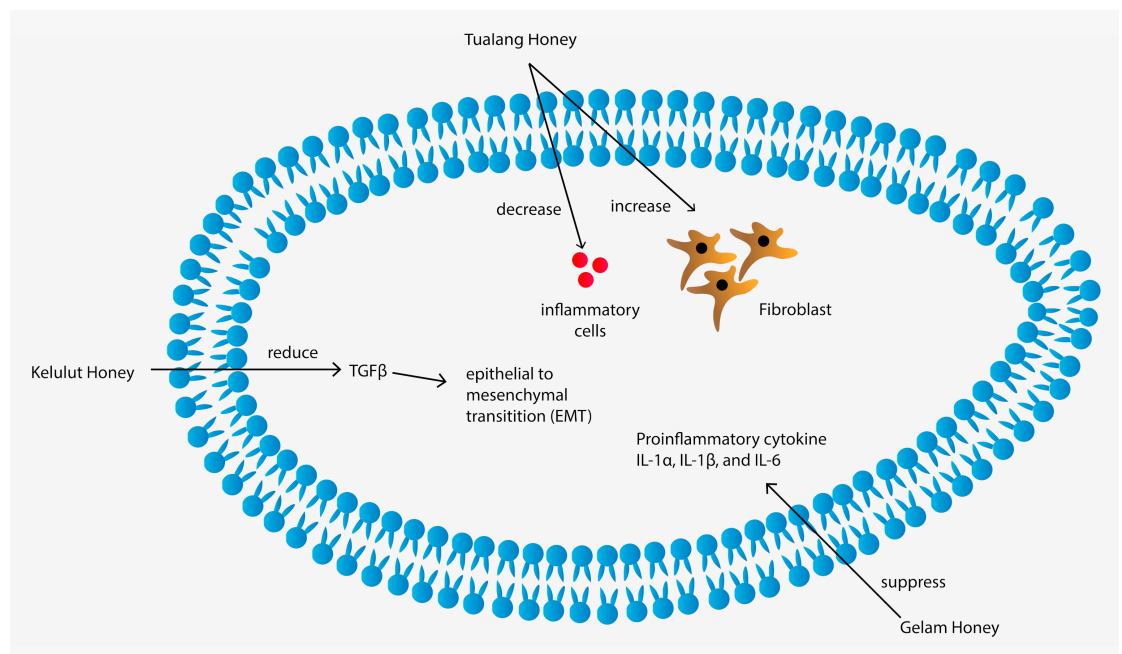

Figure 5. Wound-healing mechanism of Tualang, Gelam and Kelulut honeys. TGF $\beta$ : transforming growth factor beta; IL-1 $\alpha$ : interleukin- $1 \alpha$; IL-1 $\beta$ : interleukin-1 $\beta$; IL-6: interleukin-6.

\subsection{Effects on Cardiovascular System}

Only Tualang honey was reported to affect the cardiovascular system in three animal studies [134-136], one study of combined in-vivo and in vitro techniques [137] and two human studies [111,112]. The studies are listed in Table 10. All animal studies reported a positive effect of Tualang honey on the cardiovascular system, whilst human studies reported varied results. Khalil et al. (2015) showed that the pretreatment of ischaemic rats with Tualang honey yielded significant protective effects on cardiac troponin I, triglycerides 
and total cholesterol. The authors contributed to improving the endogenous antioxidant enzyme activity and inhibition of lipid peroxidation by Tualang honey [134]. Two studies reported that Tualang honey supplementation considerably reduced elevated systolic blood pressure via amelioration of spontaneous hypertensive rats $[135,136]$. Devasvaran et al. (2019) stated that in vitro Tualang honey could inhibit $\mathrm{H}_{2} \mathrm{O}_{2}$-induced vascular hyperpermeability in vitro and in vivo by suppressing adherence junction protein redistribution via calcium and cAMP [137].

A randomised controlled trial comparing the effects of Tualang honey and hormone replacement therapy for 4 months showed no demonstrable effects on blood pressure measurement, BMI and waist circumference. No significant difference was found in the lipid profile, blood sugar profile and bone density between the two groups. However, a statistically significant increase in total cholesterol, low-density lipoprotein cholesterol (LDL-C) and FBS levels was observed in the honey-treated group at 4 months of the study compared with the baseline value [111]. A study on humans compared the effect of $20 \mathrm{~g}$ Tualang honey only and honey cocktail (a mixture of Tualang honey, beebread and royal jelly) for 12 months. Supplementation of Tualang honey only showed a significant effect in lowering diastolic blood pressure and FBS compared with supplementation of honey cocktail. However, no demonstrable effect of Tualang honey on the lipid profiles and anthropometric measurements was found [112].

Table 10. Summary of the effects on cardiovascular system.

\begin{tabular}{|c|c|c|c|}
\hline Type of Honey & Type of Study & Findings & References \\
\hline Tualang honey & In vitro and in vivo & $\begin{array}{l}\text { Tualang honey could inhibit } \mathrm{H}_{2} \mathrm{O}_{2} \text {-induced vascular hyperpermeability } \\
\text { in vitro and in vivo by suppressing adherence junction protein } \\
\text { redistribution via calcium and cyclic adenosine } \\
\text { monophosphate (cAMP). }\end{array}$ & [137] \\
\hline Tualang honey & In vivo & $\begin{array}{l}\text { Pre-treatment with Tualang honey demonstrated cardioprotective } \\
\text { effects on isoproterenol-induced myocardial infarction in rats by } \\
\text { improving cardiac marker enzyme and ameliorating oxidative stress. }\end{array}$ & {$[134]$} \\
\hline Tualang honey & In vivo & $\begin{array}{l}\text { Tualang honey supplementation considerably reduced elevated systolic } \\
\text { blood pressure via amelioration of oxidative stress in spontaneously } \\
\text { hypertensive rats' kidneys. }\end{array}$ & [135] \\
\hline Tualang honey & In vivo & $\begin{array}{l}\text { Tualang honey ameliorated oxidative stress and reduced elevated blood } \\
\text { pressure in spontaneous hypertensive rats but not in diabetic rats. }\end{array}$ & {$[136]$} \\
\hline Tualang honey & Human study & $\begin{array}{l}\text { Tualang Honey supplementation showed a superior effect in lowering } \\
\text { diastolic blood pressure and fasting blood sugar over honey cocktail (a } \\
\text { mixture of honey, beebread and royal jelly) in postmenopausal women. }\end{array}$ & {$[112]$} \\
\hline Tualang honey & Human study & $\begin{array}{l}\text { Four months of Tualang honey supplementation in postmenopausal } \\
\text { women showed no changes in blood pressure, waist circumference, } \\
\text { BMI, lipid profile, blood sugar and bone density compared with } \\
\text { low-dose hormone replacement therapy. }\end{array}$ & {$[111]$} \\
\hline
\end{tabular}

\subsection{Effects on Reproductive System}

Tualang, Gelam and Kelulut honeys demonstrated benefits toward male and female reproductive systems. All of these benefits are listed in Table 11. Findings from animal studies have shown that Tualang honey is beneficial for the postmenopausal syndrome. Amongst the benefits are preventing uterine atrophy, increasing bone density and suppressing body weight elevation [138]. Ovariectomised rats that received Tualang honey showed more trabecular bone structure improvements than those who received calcium supplements [139]. These findings may suggest the potential of Tualang honey as an alternative to hormone replacement therapy for postmenopausal women.

Moreover, Tualang honey appeared to have a protective role against bisphenol-A (BPA)-induced toxicity in rat uterus by improving the morphological abnormalities, reducing lipid peroxidation and normalising $\mathrm{ER} \alpha, \mathrm{ER} \beta$ and $\mathrm{C} 3$ expression distribution in the rat uterus [140]. The same protective effect was also exhibited in BPA-induced ovarian toxicity, 
where Tualang honey reduced the morphological abnormalities of the ovarian follicles and improved the normal estrous cycle [141].

In the male reproductive system, Tualang honey at a dose of $1.2 \mathrm{~g} / \mathrm{kg} /$ day is the most effective dose to alter the male reproductive parameter as it significantly increased epididymal sperm count [142]. This finding is parallel with the result of the other two studies using $1.2 \mathrm{~g} / \mathrm{kg} /$ day of Tualang honey treatment that successfully demonstrated Tualang honey's benefit on the male reproductive system $[143,144]$. In response to impaired sexual behavior and fertility, Tualang honey was revealed to have a protective effect against cigarette smoke-induced impaired sexual behavior and fertility in male rats by significantly increasing intromission and ejaculation and increasing mating fertility indices [143]. In a separate study, Tualang honey supplementation during prenatal restraint stress significantly increased testis and epididymis weights. It improved the percentages of abnormal spermatozoa and sperm motility in male rat offspring [144]. In humans, a randomised control study showed that the effect of Tualang honey amongst oligospermic males was comparable with that of Tribestan in improving sperm concentration, motility and morphology [145]. Apart from Tualang honey, Kelulut honey has been shown to benefit the male reproductive system. In streptozotocin-induced diabetic rats, Kelulut honey treatment prevented sperm and testicular oxidative damage by improving sperm quality and increasing the spermatozoa and spermatogenic cells [55]. One possible mechanism is the anti-oxidative properties that are mostly attributed to the phenolic and flavonoid contents of honey. For support, Budin et al. (2017) reported increased SOD and GSH activities and decreased PC and MDA levels in sperm and testis of streptozotocin-induced diabetic rats [55].

Tualang honey has been shown to have various advantages for female and male reproductive systems. However, future works should explore the chemical constituents responsible for the reproductive effect of Tualang and Kelulut honeys. Meanwhile, Gelam honey has not been explored for its effect on the reproductive system.

Table 11. Summary of the effects on reproductive system.

\begin{tabular}{|c|c|c|c|}
\hline Type of Honey & Type of Study & Findings & References \\
\hline Tualang honey & In vivo & $\begin{array}{l}\text { The Tualang honey-treated group showed more trabecular bone structure } \\
\text { improvements than experimental postmenopausal rats who received calcium. }\end{array}$ & {$[139]$} \\
\hline Tualang honey & In vivo & $\begin{array}{l}\text { Tualang honey prevented uterine atrophy, increased bone density and } \\
\text { suppressed increased body weight in ovariectomised rats. }\end{array}$ & [138] \\
\hline Kelulut honey & In vivo & Kelulut honey prevented damage of sperm and testis in diabetic rats. & {$[55]$} \\
\hline Tualang honey & In vivo & Tualang honey protected the uterus from bisphenol-A (BPA)-induced toxicity. & {$[140]$} \\
\hline Tualang honey & In vivo & $\begin{array}{l}\text { Tualang honey demonstrated a protective effect against cigarette } \\
\text { smoke-induced impaired sexual behaviour and fertility in male rats. }\end{array}$ & [143] \\
\hline Tualang honey & In vivo & $\begin{array}{l}\text { Tualang honey at a dose of } 1.2 \mathrm{~g} \mathrm{~kg} \text { daily increased epididymal sperm count } \\
\text { without affecting spermatid count and reproductive hormones. }\end{array}$ & [142] \\
\hline Tualang honey & In vivo & $\begin{array}{l}\text { Tualang honey supplementation during pregnancy reduced the adverse } \\
\text { effects of prenatal restraint stress on reproductive organ weight and sperm } \\
\text { parameters in male rat offspring. }\end{array}$ & {$[144]$} \\
\hline Tualang honey & In vivo & $\begin{array}{l}\text { Tualang honey reduced BPA-induced ovarian toxicity by reducing the ovarian } \\
\text { follicles' morphological abnormalities and improving the normal } \\
\text { oestrous cycle. }\end{array}$ & {$[141]$} \\
\hline Tualang honey & Human study & $\begin{array}{l}\text { The Tualang honey effect amongst oligospermic males was comparable with } \\
\text { that of Tribestan in improving sperm concentration, motility and morphology. }\end{array}$ & {$[145]$} \\
\hline
\end{tabular}

\subsection{Effects on Nervous System}

The effect of Tualang, Gelam and Kelulut honeys on the nervous system is summarised in Table 12. Tualang honey has been reported in several studies to improve memory and reduce depressive-like behavior in animals and humans. In noise stress-induced memory deficits in aged rats, Tualang honey administration was shown to protect against memory 
decline via enhancement of medial prefrontal cortex and hippocampal morphology, possibly through the reduction of brain oxidative stress and the up-regulation of brain-derived neurotrophic factor (BDNF) concentration and cholinergic system [146]. These findings were further corroborated by Azman et al. (2015), who showed that Tualang honey administration improved memory performance and decreased depressive-like behavior in rats exposed to loud noise stress [147].

Several clinical studies have found that oestrogen treatment has a protective effect on aging women's cognitive decline [148]. In a study on stressed ovariectomised rats, Tualang honey or $17 \beta$-estradiol treatment has been shown to demonstrate antidepressive-like effects, possibly via restoration of the hypothalamic-pituitary-adrenal axis and enhancement of the BDNF concentration [149]. In the same set of studies, rats administered with Tualang honey or $17 \beta$ estradiol showed improved short-term and long-term memory and enhanced neuronal proliferation of hippocampal CA2, CA3 and dentate gyrus (DG) regions compared with untreated stressed ovariectomised rats [150]. In addition, Al-Rahbi et al. (2014) demonstrated the anti-anxiety effect of Tualang honey in ovariectomised rats with the improvement of its oxidative stress status [151]. A randomised controlled trial comparing Tualang honey supplementation and oestrogen plus progestin therapy demonstrated that postmenopausal women who received Tualang honey showed improvements in their immediate memory but not in immediate memory after the interference and delayed recall as oestrogen plus progestin therapy. However, this finding is comparable with the improvement seen in women receiving oestrogen plus progestin treatment [152]. These animal and human studies may serve as a basis to propose Tualang honey as a potential supplement with comparable effects as oestrogen and with no side effects in postmenopausal women.

Tualang honey has been reported in several studies to exert a neuroprotective effect through its antioxidant properties. In a study of kainic acid KA-treated rats, pretreatment with Tualang honey reduced the KA-induced neuronal degeneration in the piriform cortex but failed to prevent the occurrence of KA-induced seizures. In addition, KA-induced rats showed increased locomotor activity and hyperactivity, which were attenuated by Tualang honey pretreatment [103]. A recent study reported that Tualang honey pretreatment significantly attenuated an increase in lipid peroxidation level and decreased the total antioxidant status level induced by KA treatment in the rat cerebral cortex. These findings indicated that pretreatment with Tualang honey has therapeutic potential against KAinduced oxidative stress and neurodegeneration through its antioxidant effect [153]. In a separate study, Tualang honey improved the oxidative stress status, spinal cord morphology and nociceptive behavior in offspring of prenatally stressed rats [154]. The anti-nociceptive effect of Tualang honey was again demonstrated in another study that showed a similar reduction in pain behavior as the prednisolone-treated group [155]. Finally, Tualang honey pretreatment was shown to be comparable with ubiquinol in protecting the rat midbrain, lung toxicity and oxidative stress against repeated paraquat exposure [156].

Regarding Kelulut honey, a study on metabolic disease-induced rats showed that the Kelulut honey-treated group exhibited less anxious behavior and demonstrated significant memory retention than the untreated metabolic disease-induced group [113]. However, the underlying mechanism of Kelulut honey in showing this benefit has yet to be discovered by researchers.

Table 12. Summary of the effect on nervous system.

\begin{tabular}{ccll}
\hline Type of Honey & Type of Study & \multicolumn{1}{c}{ Findings } \\
\hline Kelulut honey & In vivo & $\begin{array}{l}\text { Kelulut honey reduced serum triglyceride and LDL and normalised blood } \\
\text { glucose levels in metabolic disease-induced rats. Behavioural studies } \\
\text { showed lessened anxious behaviour and enhanced memory retention. }\end{array}$ \\
\hline Tualang honey & In vivo & $\begin{array}{l}\text { Tualang honey improved memory performance and decreased } \\
\text { depressive-like behaviour in rats exposed to loud noise stress. }\end{array}$ \\
\hline Tualang honey & In vivo & $\begin{array}{l}\text { Tualang honey or 17ß-oestradiol treatment demonstrated } \\
\text { anti-depressive-like effects, possibly via restoration of the } \\
\text { hypothalamic-pituitary-adrenal axis and enhancement of the brain-derived } \\
\text { neurotrophic factor (BDNF) concentration in stressed ovariectomised rats. }\end{array}$ \\
\hline
\end{tabular}


Table 12. Cont.

\begin{tabular}{|c|c|c|c|}
\hline Type of Honey & Type of Study & Findings & References \\
\hline Tualang honey & In vivo & $\begin{array}{l}\text { Administration of either oestrogen or Tualang honey significantly decreased } \\
\text { anxiety-like behaviour in stressed ovariectomised rats, with improved } \\
\text { oxidative stress status. }\end{array}$ & {$[151]$} \\
\hline Tualang honey & In vivo & $\begin{array}{l}\text { Tualang honey and oestrogen treatments improved short-term and } \\
\text { long-term memory and enhanced the neuronal proliferation of } \\
\text { hippocampal CA2, CA3 and DG regions in stressed ovariectomised rats. }\end{array}$ & {$[150]$} \\
\hline Tualang honey & In vivo & $\begin{array}{l}\text { Pre-treatment with Tualang honey reduced kainic acid-induced neuronal } \\
\text { degeneration, hyperactivity and oxidative stress but failed to } \\
\text { prevent seizures. }\end{array}$ & {$[153]$} \\
\hline Tualang honey & In vivo & $\begin{array}{l}\text { Tualang honey protected against memory decline due to noise stress } \\
\text { exposure and ageing via enhancement of medial prefrontal cortex and } \\
\text { hippocampal morphology, possibly secondary to a reduction in brain } \\
\text { oxidative stress and upregulation BDNF concentration and the } \\
\text { cholinergic system. }\end{array}$ & {$[146]$} \\
\hline Tualang honey & In vivo & $\begin{array}{l}\text { Treatment with Tualang honey ameliorated the toxic effects induced by } \\
\text { repeated paraquat exposure observed in midbrain and lungs. Tualang } \\
\text { honey effect was comparable to that of ubiquinol. }\end{array}$ & {$[156]$} \\
\hline Tualang honey & In vivo & $\begin{array}{l}\text { Tualang honey improved oxidative stress status and spinal cord } \\
\text { morphology and nociceptive behaviour in the offspring of prenatally } \\
\text { stressed rats. }\end{array}$ & {$[154]$} \\
\hline Tualang honey & In vivo & $\begin{array}{l}\text { Pre-treatment with Tualang honey }(1.2 \text { and } 2.4 \mathrm{~g} / \mathrm{kg}) \text { and prednisolone } \\
(10 \mathrm{mg} / \mathrm{kg}) \text { reduced pain responses in the rat. }\end{array}$ & [155] \\
\hline Tualang honey & In vivo & $\begin{array}{l}\text { Postmenopausal women who received Tualang honey showed } \\
\text { improvement in their immediate memory but not in immediate memory } \\
\text { after interference and delayed recall. This finding was comparable to the } \\
\text { improvement observed in women receiving oestrogen plus } \\
\text { progestin therapy. }\end{array}$ & {$[152]$} \\
\hline
\end{tabular}

\section{Conclusions}

Tualang, Gelam and Kelulut honeys were extensively demonstrated to have various health benefits to multiple diseases and systems. Clinical trials, especially in wound healing, showed the superior benefit of Tualang honey as a wound dressing over conventional dressing. However, clinical trials using Tualang, Gelam, and Kelulut honeys are still needed to add to the results because convincing effects are still yet to be finalised. In addition, the mechanism of action of these honeys was not clear, especially in human studies, thereby leaving an area to be discovered. In comparison, Tualang and Gelam honeys have been well researched compared with Kelulut honey. Thus, future studies may focus more on the potential benefit of Kelulut honey. This study also revealed that Tualang, Gelam and Kelulut honey has excellent preclinical potential in multiple diseases and physiological systems that could steer future research to thoroughly explore honey as an efficient and proven superfood to be optimised for the benefit of humanity.

Author Contributions: Conceptualization, D.A.M.K., M.H.M., S.F.I. and M.I.A.M.K.; methodology, M.H.M. and D.A.M.K.; writing-original draft preparation, D.A.M.K.; Illustration, H.K., writingreview and editing, M.H.M., H.K. and M.I.A.M.K.; supervision, M.H.M. and S.F.I. All authors have read and agreed to the published version of the manuscript.

Funding: This research was funded by Universiti Kebangsaan Malaysia (Faculty of Medicine Fundamental Grant; grant number FF-2020-241).

Institutional Review Board Statement: Not applicable.

Informed Consent Statement: Not applicable.

Data Availability Statement: Data sharing is not applicable to this article.

Conflicts of Interest: The authors declare no conflict of interest. 


\section{References}

1. Fletcher, M.T.; Hungerford, N.L.; Webber, D.; De Jesus, M.C.; Zhang, J.; Stone, I.S.J.; Blanchfield, J.T.; Zawawi, N. Stingless bee honey, a novel source of trehalulose: A biologically active disaccharide with health benefits. Sci. Rep. 2020, 10, 1-8. [CrossRef]

2. Abuelgasim, H.; Albury, C.; Lee, J. Effectiveness of honey for symptomatic relief in upper respiratory tract infections: A systematic review and meta-analysis. BMJ Evid. Based Med. 2020. [CrossRef]

3. Yaghoobi, R.; Kazerouni, A.; Kazerouni, O. Evidence for Clinical Use of Honey in Wound Healing as an Anti-bacterial, Anti-inflammatory Anti-oxidant and Anti-viral Agent: A Review. Jundishapur J. Nat. Pharm. Prod. 2013, 8, 100-104. [CrossRef] [PubMed]

4. Jull, A.; Cullum, N.; Dumville, J.C.; Westby, M.J.; Deshpande, S.; Walker, N. Honey as a topical treatment for wounds. Cochrane Database Syst. Rev. 2015, CD005083. [CrossRef]

5. Simon, A.; Traynor, K.; Santos, K.; Blaser, G.; Bode, U.; Molan, P. Medical Honey for Wound Care-Still the 'Latest Resort'? Evid. Based Complement. Altern. Med. 2009, 6, 165-173. [CrossRef]

6. Ahmed, S.; Othman, N.H. Review of the Medicinal Effects of Tualang Honey and a Comparison with Manuka Honey. Malays. J. Med Sci. 2013, 20, 6-13.

7. Devasvaran, K.; Yong, Y.-K. Anti-inflammatory and wound healing properties of Malaysia Tualang honey. Curr. Sci. $2016,110,47-51$.

8. Chan, B.K.; Haron, H. Insights into Putative Health Implications of Gelam (Melaleuca cajuputi) Honey: Evidence from In-Vivo and In-Vitro Studies. Med. Sci. 2016, 4, 3. [CrossRef]

9. Zainol, M.I.; Yusoff, K.M.; Yusof, M.Y. Antibacterial activity of selected Malaysian honey. BMC Complement. Altern. Med. 2013, 13, 129. [CrossRef]

10. Yaacob, M.; Rajab, N.; Shahar, S.; Sharif, R. Stingless bee honey and its potential value: A systematic review. Food Res. 2017, 2, 124-133. [CrossRef]

11. Ramli, E.S.; Kamaruzzaman, M.A.; Thanu, A.; Yusof, M.R.; Soelaiman, I.N. Kelulut honey ameliorates glucocorticoid induced osteoporosis via its antioxidant activity in rats. Asian Pac. J. Trop. Biomed. 2019, 9, 493. [CrossRef]

12. EC. Council directive 2001/110/EC of 20 December 2001 relating honey. Off. J. Eur. Communities 2001, 10, 47-52.

13. Codex Alimentarius Commission. Revised Codex Standard for Honey. In Standards and Standard Methods; WHO \& FAO: Rome, Italy, 2001.

14. Standard, M. MS 2683: 2017: Kelulut (Stingless Bee) Honey-Specification: Quality Requirements; Department of Standards Malaysia: Selangor, Malaysia, 2017.

15. Chua, L.S.; Abdul-Rahaman, N.-L.; Sarmidi, M.R.; Aziz, R. Multi-elemental composition and physical properties of honey samples from Malaysia. Food Chem. 2012, 135, 880-887. [CrossRef] [PubMed]

16. A-Rahaman, N.L.; Chua, L.S.; Sarmidi, M.R.; Aziz, R. Physicochemical and radical scavenging activities of honey samples from Malaysia. Agric. Sci. 2013, 4, 46-51. [CrossRef]

17. Baloš, M.Ž.; Popov, N.; Vidaković, S.; Pelić, D.L.; Pelić, M.; Mihaljev, Ž.; Jakšić, S. Electrical conductivity and acidity of honey. Arch. Vet. Med. 2018, 11, 91-101. [CrossRef]

18. Thrasyvoulou, A.; Tananaki, C.; Goras, G.; Karazafiris, E.; Dimou, M.; Liolios, V.; Kanelis, D.; Gounari, S. Legislation of honey criteria and standards. J. Apic. Res. 2018, 57, 88-96. [CrossRef]

19. Amin, F.A.Z.; Sabri, S.; Mohammad, S.M.; Ismail, M.; Chan, K.W.; Ismail, N.; Norhaizan, M.E.; Zawawi, N. Therapeutic Properties of Stingless Bee Honey in Comparison with European Bee Honey. Adv. Pharmacol. Sci. 2018, 2018, 1-12. [CrossRef]

20. Hussein, S.Z.; Yusoff, K.M.; Makpol, S.; Yusof, Y.A.M. Antioxidant Capacities and Total Phenolic Contents Increase with Gamma Irradiation in Two Types of Malaysian Honey. Molecules 2011, 16, 6378-6395. [CrossRef]

21. Chua, L.S.; Rahaman, N.L.A.; Adnan, N.A.; Tan, T.T.E. Antioxidant Activity of Three Honey Samples in relation with Their Biochemical Components. J. Anal. Methods Chem. 2013, 2013, 1-8. [CrossRef]

22. Kek, S.P.; Chin, N.L.; Yusof, Y.A.; Tan, S.W.; Chua, L.S. Total Phenolic Contents and Colour Intensity of Malaysian Honeys from the Apis spp. and Trigona spp. Bees. Agric. Agric. Sci. Procedia 2014, 2, 150-155. [CrossRef]

23. Tomczyk, M.; Tarapatskyy, M.; Dżugan, M. The influence of geographical origin on honey composition studied by Polish and Slovak honeys. Czech J. Food Sci. 2019, 37, 232-238. [CrossRef]

24. Khalafi, R.; Goli, S.A.H.; Behjatian, M. Characterization and Classification of Several Monofloral Iranian Honeys Based on Physicochemical Properties and Antioxidant Activity. Int. J. Food Prop. 2016, 19, 1065-1079. [CrossRef]

25. Kek, S.P.; Chin, N.L.; Yusof, Y.A.; Tan, S.W.; Chua, L.S. Classification of entomological origin of honey based on its physicochemical and antioxidant properties. Int. J. Food Prop. 2017, 20, S2723-S2738. [CrossRef]

26. Khalil, I.; Mahaneem, M.; Jamalullail, S.M.S.; Alam, N.; Sulaiman, S.A. Evaluation of radical scavenging activity and colour intensity of nine Malaysian honeys of different origin. J. ApiProd. ApiMed. Sci. 2011, 3, 4-11. [CrossRef]

27. Zae, T.; Azlan, A.; Sajak, A.A.B.; Hock, E.; Chin, N.L.; Noh, M.M.; Khalid, N.M. Comparison of selected local honey with Manuka honey based on their nutritional and antioxidant properties. Food Res. 2020, 4, 205-213. [CrossRef]

28. Moniruzzaman, M.; Chowdhury, M.A.Z.; Rahman, M.A.; Sulaiman, S.A.; Gan, S.H. Determination of Mineral, Trace Element, and Pesticide Levels in Honey Samples Originating from Different Regions of Malaysia Compared to Manuka Honey. BioMed Res. Int. 2014, 2014, 1-10. [CrossRef]

29. Moniruzzaman, M.; Khalil, I.; Sulaiman, S.A.; Gan, S.H. Physicochemical and antioxidant properties of Malaysian honeys produced by Apis cerana, Apis dorsata and Apis mellifera. BMC Complement. Altern. Med. 2013, 13, 43. [CrossRef] 
30. Moniruzzaman, M.; Sulaiman, S.A.; Khalil, I.; Gan, S.H. Evaluation of physicochemical and antioxidant properties of sourwood and other Malaysian honeys: A comparison with manuka honey. Chem. Cent. J. 2013, 7, 138. [CrossRef]

31. Shamsudin, S.; Selamat, J.; Sanny, M.; Razak, S.B.B.A.; Jambari, N.N.; Khatib, A. A Comparative Characterization of Physicochemical and Antioxidants Properties of Processed Heterotrigona itama Honey from Different Origins and Classification by Chemometrics Analysis. Molecules 2019, 24, 3898. [CrossRef]

32. Chua, L.S.; Adnan, N.A. Biochemical and nutritional components of selected honey samples. Acta Sci. Pol. Technol. Aliment. 2014, 13, 169-179. [CrossRef]

33. Wong, P.; Hii, S.L.; Koh, C.C.; Moh, T.S.Y.; Gindi, S.R.A. Chemical Analysis on the Honey of Heterotrigona itama and Tetrigona binghami from Sarawak, Malaysia. Sains Malays. 2019, 48, 1635-1642. [CrossRef]

34. Lim, D.C.C.; Abu Bakar, M.F.; Majid, M. Nutritional composition of stingless bee honey from different botanical origins. IOP Conf. Ser. Earth Environ. Sci. 2019, 269, 012025. [CrossRef]

35. Julika, W.N.; Ajit, A.B.; Sulaiman, A.Z.; Naila, A. Physicochemical and Microbiological Analysis of Stingless Bees Honey Collected from Local Market in Malaysia. Indones. J. Chem. 2019, 19, 522-530. [CrossRef]

36. Kek, S.P.; Chin, N.L.; Tan, S.W.; Yusof, Y.A.; Chua, L.S. Classification of Honey from Its Bee Origin via Chemical Profiles and Mineral Content. Food Anal. Methods 2017, 10, 19-30. [CrossRef]

37. Mohamed, M.; Sirajudeen, K.; Swamy, M.; Yaacob, N.S.; Sulaiman, S.A. Studies on the antioxidant properties of Tualang honey of Malaysia. Afr. J. Tradit. Complement. Altern. Med. 2010, 7, 59-63. [CrossRef] [PubMed]

38. Kishore, R.K.; Halim, A.S.; Syazana, M.; Sirajudeen, K. Tualang honey has higher phenolic content and greater radical scavenging activity compared with other honey sources. Nutr. Res. 2011, 31, 322-325. [CrossRef]

39. Yao, L.; Razak, S.; Ismail, N.; Fai, N.; Asyraf, M.; Sharif, G.; Jubri, Z. Malaysian gelam honey reduces oxidative damage and modulates antioxidant enzyme activities in young and middle aged rats. J. Med. Plant Res. 2011, 5, 5618-5625.

40. Sahhugi, Z.; Hasenan, S.; Jubri, Z. Research Article Protective Effects of Gelam Honey against Oxidative Damage in Young and Aged Rats. Oxidative Med. Cell. Longev. 2014, 2014, 1-8. [CrossRef]

41. Sani, N.F.A.; Belani, L.K.; Sin, C.P.; Rahman, S.N.A.A.; Das, S.; Chi, T.Z.; Makpol, S.; Yusof, Y.A.M. Effect of the Combination of Gelam Honey and Ginger on Oxidative Stress and Metabolic Profile in Streptozotocin-Induced Diabetic Sprague-Dawley Rats. BioMed Res. Int. 2014, 2014, 1-9. [CrossRef]

42. Ahmad, T.A.F.T.; Jubri, Z.; Rajab, N.F.; Rahim, K.A.; Yusof, Y.A.M.; Makpol, S. Gelam Honey Protects against Gamma-Irradiation Damage to Antioxidant Enzymes in Human Diploid Fibroblasts. Molecules 2013, 18, 2200-2211. [CrossRef]

43. Carlson, C.J.; Koterski, S.; Sciotti, R.J.; Poccard, G.B.; Rondinone, C.M. Enhanced basal activation of mitogen-activated protein kinases in adipocytes from type 2 diabetes: Potential role of p38 in the downregulation of GLUT4 expression. Diabetes 2003, 52, 634-641. [CrossRef] [PubMed]

44. Evans, J.L.; Goldfine, I.D.; Maddux, B.A.; Grodsky, G.M. Are Oxidative Stress-Activated Signaling Pathways Mediators of Insulin Resistance and -Cell Dysfunction? Diabetes 2003, 52, 1-8. [CrossRef] [PubMed]

45. Batumalaie, K.; Safi, S.Z.; Yusof, K.M.; Bin Ismail, I.S.; Sekaran, S.D.; Qvist, R. Effect of Gelam Honey on the Oxidative StressInduced Signaling Pathways in Pancreatic Hamster Cells. Int. J. Endocrinol. 2013, 2013, 1-10. [CrossRef] [PubMed]

46. Safi, S.Z.; Batumalaie, K.; Qvist, R.; Yusof, K.M.; Bin Ismail, I.S. Gelam Honey Attenuates the Oxidative Stress-Induced Inflammatory Pathways in Pancreatic Hamster Cells. Evid. Based Complement. Altern. Med. 2016, 2016, 1-13. [CrossRef] [PubMed]

47. Batumalaie, K.; Qvist, R.; Yusof, K.M.; Ismail, I.S.; Sekaran, S.D. The antioxidant effect of the Malaysian Gelam honey on pancreatic hamster cells cultured under hyperglycemic conditions. Clin. Exp. Med. 2014, 14, 185-195. [CrossRef] [PubMed]

48. Erejuwa, O.O.; Sulaiman, S.A.; Wahab, M.S.; Sirajudeen, K.N.S.; Salleh, M.S.M.D.; Gurtu, S. Antioxidant protection of Malaysian tualang honey in pancreas of normal and streptozotocin-induced diabetic rats. Ann. D'Endocrinol. 2010, 71, 291-296. [CrossRef] [PubMed]

49. Erejuwa, O.O.; Sulaiman, S.A.; Ab Wahab, M.S.; Sirajudeen, K.N.S.; Salleh, S.M.; Gurtu, S. Antioxidant Protective Effect of Glibenclamide and Metformin in Combination with Honey in Pancreas of Streptozotocin-Induced Diabetic Rats. Int. J. Mol. Sci. 2010, 11, 2056-2066. [CrossRef]

50. Omotayo, E.O.; Gurtu, S.; Sulaiman, S.A.; Ab Wahab, M.S.; Salam, S.K.N.; Salleh, S.M. Hypoglycemic and Antioxidant Effects of Honey Supplementation in Streptozotocin-induced Diabetic Rats. Int. J. Vitam. Nutr. Res. 2010, 80, 74-82. [CrossRef]

51. Erejuwa, O.O.; Sulaiman, S.A.; Ab Wahab, M.S.; Sirajudeen, K.N.S.; Salleh, S.M.; Gurtu, S. Comparison of Antioxidant Effects of Honey, Glibenclamide, Metformin, and Their Combinations in the Kidneys of Streptozotocin-Induced Diabetic Rats. Int. J. Mol. Sci. 2011, 12, 829-843. [CrossRef]

52. Tan, J.J.; Azmi, S.M.; Yong, Y.K.; Cheah, H.L.; Lim, V.; Sandai, D.; Shaharuddin, B. Tualang Honey Improves Human Corneal Epithelial Progenitor Cell Migration and Cellular Resistance to Oxidative Stress In Vitro. PLoS ONE 2014, 9, e96800. [CrossRef]

53. Bashkaran, K.; Zunaina, E.; Bakiah, S.; Sulaiman, S.A.; Sirajudeen, K.; Naik, V.R. Anti-inflammatory and antioxidant effects of Tualang honey in alkali injury on the eyes of rabbits: Experimental animal study. BMC Complement. Altern. Med. 2011, 11, 90. [CrossRef] [PubMed]

54. Ahmad, N.S.; Aziz, A.A.; Kong, K.W.; Hamid, M.S.A.; Cheong, J.P.G.; Hamzah, S.H. Dose-Response Effect of Tualang Honey on Postprandial Antioxidant Activity and Oxidative Stress in Female Athletes: A Pilot Study. J. Altern. Complement. Med. 2017, 23, 989-995. [CrossRef] [PubMed] 
55. Budin, S.; Jubaidi, F.; Azam, S.; Mohammed Yusof, N.; Taib, I.S.; Mohamed, J. Kelulut honey supplementation prevents sperm and testicular oxidative damage in streptozotocin-induced diabetic rats. J. Teknol. 2017, 79. [CrossRef]

56. Socha, R.; Juszczak, L.; Pietrzyk, S.; Fortuna, T. Antioxidant activity and phenolic composition of herbhoneys. Food Chem. 2009, 113, 568-574. [CrossRef]

57. Jibril, F.I.; Hilmi, A.B.M.; Manivannan, L. Isolation and characterization of polyphenols in natural honey for the treatment of human diseases. Bull. Natl. Res. Cent. 2019, 43, 4. [CrossRef]

58. Ahmed, S.; Sulaiman, S.A.; Baig, A.A.; Ibrahim, M.; Liaqat, S.; Fatima, S.; Jabeen, S.; Shamim, N.; Othman, N.H. Honey as a Potential Natural Antioxidant Medicine: An Insight into Its Molecular Mechanisms of Action. Oxidative Med. Cell. Longev. 2018, 2018, 1-19. [CrossRef]

59. Ahmed, S.; Othman, N.H. The anti-cancer effects of Tualang honey in modulating breast carcinogenesis: An experimental animal study. BMC Complement. Altern. Med. 2017, 17, 208. [CrossRef]

60. Kadir, E.A.; Sulaiman, S.A.; Yahya, N.K.; Othman, N.H. Inhibitory Effects of Tualang Honey on Experimental Breast Cancer in Rats: A Preliminary Study. Asian Pac. J. Cancer Prev. 2013, 14, 2249-2254. [CrossRef]

61. Ahmed, S.; Sulaiman, S.A.; Othman, N.H. Oral Administration of Tualang and Manuka Honeys Modulates Breast Cancer Progression in Sprague-Dawley Rats Model. Evid. Based Complement. Altern. Med. 2017, 2017, 1-15. [CrossRef]

62. Fauzi, A.N.; Norazmi, M.N.; Yaacob, N.S. Tualang honey induces apoptosis and disrupts the mitochondrial membrane potential of human breast and cervical cancer cell lines. Food Chem. Toxicol. 2011, 49, 871-878. [CrossRef]

63. Yaacob, N.S.; Nengsih, A.; Norazmi, M.N. Tualang Honey Promotes Apoptotic Cell Death Induced by Tamoxifen in Breast Cancer Cell Lines. Evid. Based Complement. Altern. Med. 2013, 2013, 1-9. [CrossRef] [PubMed]

64. Yaacob, N.S.; Ismail, N.F. Comparison of cytotoxicity and genotoxicity of 4-hydroxytamoxifen in combination with Tualang honey in MCF-7 and MCF-10A cells. BMC Complement. Altern. Med. 2014, 14, 106. [CrossRef] [PubMed]

65. Hizan, N.S.; Hassan, N.H.M.; Haron, J.; Abubakar, M.B.; Mahdi, N.M.N.; Gan, S.H. Tualang honey adjunct with anastrozole improve parenchyma enhancement of breast tissue in breast cancer patients: A randomized controlled trial. Integr. Med. Res. 2018, 7, 322-327. [CrossRef] [PubMed]

66. Al-Koshab, M.; AlAbsi, A.M.; Bakri, M.M.; Naicker, M.S.; Seyedan, A. Chemopreventive activity of Tualang honey against oral squamous cell carcinoma-In vivo. Oral Surg. Oral Med. Oral Pathol. Oral Radiol. 2020, 129, 484-492. [CrossRef]

67. Ghashm, A.A.; Othman, N.H.; Khattak, M.N.; Ismail, N.M.; Saini, R. Antiproliferative effect of Tualang honey on oral squamous cell carcinoma and osteosarcoma cell lines. BMC Complement. Altern. Med. 2010, 10, 49. [CrossRef]

68. Man, N.M.K.N.; Hassan, R.; Ang, C.Y.; Abdullah, A.D.; Radzi, M.A.R.M.; Sulaiman, S.A. Antileukemic Effect of Tualang Honey on Acute and Chronic Leukemia Cell Lines. BioMed Res. Int. 2015, 2015, 1-7. [CrossRef]

69. Ahmad, I.; Jimenez, H.; Yaacob, N.S.; Yusuf, N. Tualang Honey Protects Keratinocytes from Ultraviolet Radiation-Induced Inflammation and DNA Damage. Photochem. Photobiol. 2012, 88, 1198-1204. [CrossRef]

70. Ramasamy, V.; Binti Mat Lazim, N.; Abdullah, B.; Singh, A. Effects of Tualang Honey on Cancer Related Fatigue: A Multicenter Open-label Trial of H\&N Cancer Patients. Gulf J. Oncol. 2019, 1, 43-51.

71. Yazan, L.S.; Zali, M.F.S.M.; Ali, R.M.; Zainal, N.A.; Esa, N.; Sapuan, S.; Ong, Y.S.; Tor, Y.S.; Gopalsamy, B.; Voon, F.L.; et al. Chemopreventive Properties and Toxicity of Kelulut Honey in Sprague Dawley Rats Induced with Azoxymethane. BioMed Res. Int. 2016, 2016, 1-6. [CrossRef]

72. Jubri, Z.; Narayanan, N.; Abdul Karim, N.; Wan Ngah, W.Z. Antiproliferative activity and apoptosis induction by gelam honey on liver cancer cell line. Int. J. Appl. Sci. Technol. 2012, 2, 135-141.

73. Hakim, L.; Alias, E.; Makpol, S.; Ngah, W.Z.W.; Morad, N.A.; Yusof, Y.A.M. Gelam Honey and Ginger Potentiate the Anti Cancer Effect of 5-FU against HCT 116 Colorectal Cancer Cells. Asian Pac. J. Cancer Prev. 2014, 15, 4651-4657. [CrossRef] [PubMed]

74. Johari, S.A.; Fatimah, H.; Ismail, W.I.W.; Ali, A.M. Corrigendum to "Combinatorial Cytotoxic Effects of Gelam Honey and 5Fluorouracil against Human Adenocarcinoma Colon Cancer HT-29 Cells In Vitro". Int. J. Cell Biol. 2019, 2019, 9050626. [CrossRef]

75. Tahir, A.A.; Sani, N.F.A.; Murad, N.A.; Makpol, S.; Ngah, W.Z.W.; Yusof, Y.A.M. Combined ginger extract \& Gelam honey modulate Ras/ERK and PI3K/AKT pathway genes in colon cancer HT29 cells. Nutr. J. 2015, 14, 1-10. [CrossRef]

76. Wee, L.H.; Morad, N.A.; Aan, G.J.; Makpol, S.; Ngah, W.Z.W.; Yusof, Y.A.M. Mechanism of Chemoprevention against Colon Cancer Cells Using Combined Gelam Honey and Ginger Extract via mTOR and Wnt/ $\beta$-catenin Pathways. Asian Pac. J. Cancer Prev. 2015, 16, 6549-6556. [CrossRef] [PubMed]

77. Ahmad, T.A.F.T.; Jaafar, F.; Jubri, Z.; Rahim, K.A.; Rajab, N.F.; Makpol, S. Gelam honey attenuated radiation-induced cell death in human diploid fibroblasts by promoting cell cycle progression and inhibiting apoptosis. BMC Complement. Altern. Med. 2014, 14, 108. [CrossRef]

78. Wen, C.T.P.; Hussein, S.Z.; Abdullah, S.; Karim, N.A.; Makpol, S.; Yusof, Y.A.M. Gelam and Nenas honeys inhibit proliferation of HT 29 colon cancer cells by inducing DNA damage and apoptosis while suppressing inflammation. Asian Pac. J. Cancer Prev. 2012, 13, 1605-1610. [CrossRef] [PubMed]

79. Cianciosi, D.; Forbes-Hernández, T.Y.; Afrin, S.; Gasparrini, M.; Reboredo-Rodríguez, P.; Manna, P.P.; Zhang, J.; Lamas, L.B.; Flórez, S.M.; Toyos, P.A.; et al. Phenolic Compounds in Honey and Their Associated Health Benefits: A Review. Molecules 2018, 23, 2322. [CrossRef]

80. Valko, M.; Leibfritz, D.; Moncol, J.; Cronin, M.T.; Mazur, M.; Telser, J. Free radicals and antioxidants in normal physiological functions and human disease. Int. J. Biochem. Cell Biol. 2007, 39, 44-84. [CrossRef] 
81. Jaganathan, S.K.; Mandal, M. Antiproliferative Effects of Honey and of Its Polyphenols: A Review. J. Biomed. Biotechnol. 2009, 2009, 1-13. [CrossRef]

82. Tumin, N.; Halim, N.; Shahjahan, M.; Noor Izani, N.; Sattar, M.A.; Khan, A.H.; Mohsin, S. Antibacterial activity of local Malaysian honey. Malays. J. Pharm. Sci. 2005, 3, 1-10.

83. Ng, W.-J.; Ken, K.-W.; Kumar, R.-V.; Gunasagaran, H.; Chandramogan, V.; Lee, Y.-Y. In-Vitro Screening of Malaysian Honey from Different Floral Sources for Antibacterial Activity on Human Pathogenic Bacteria. Afr. J. Tradit. Complement. Altern. Med. 2014, 11, 315-318. [CrossRef] [PubMed]

84. Albaridi, N.A. Antibacterial Potency of Honey. Int. J. Microbiol. 2019, 2019, 1-10. [CrossRef] [PubMed]

85. Weston, R. The contribution of catalase and other natural products to the antibacterial activity of honey: A review. Food Chem. 2000, 71, 235-239. [CrossRef]

86. Allen, K.L.; Molan, P.C.; Reid, G.M. A Survey of the Antibacterial Activity of Some New Zealand Honeys. J. Pharm. Pharmacol. 1991, 43, 817-822. [CrossRef] [PubMed]

87. Yap, P.; Bakar, M.; Lim, H.; Carrier, D. Antibacterial activity of polyphenol-rich extract of selected wild honey collected in Sabah, Malaysia. J. Apic. Res. 2015, 54, 163-172. [CrossRef]

88. Aween, M.M.; Hassan, Z.; Muhialdin, B.J.; Eljamel, Y.A.; Al-Mabrok, A.S.W.; Lani, M.N. Antibacterial Activity of Lactobacillus acidophilus Strains Isolated from Honey Marketed in Malaysia against Selected Multiple Antibiotic Resistant (MAR) GramPositive Bacteria. J. Food Sci. 2012, 77, M364-M371. [CrossRef]

89. Punitan, R.; Sulaiman, S.A.; Hasan, H.B.; Shatriah, I. Clinical and Antibacterial Effects of Tualang Honey on Pseudomonas-induced Keratitis in Rabbit Eyes. Cureus 2019, 11, e4332. [CrossRef]

90. Nasir, N.A.; Halim, A.S.; Singh, K.K.; Dorai, A.A.; Haneef, M.N. Antibacterial properties of tualang honey and its effect in burn wound management: A comparative study. BMC Complement. Altern. Med. 2010, 10, 31. [CrossRef]

91. Tang, M.L.; Rahman, R.A.; Gan, S.H.; Halim, A.S.; Hassan, S.A.; Sulaiman, S.A.; Singh, K.-K.B. The antibacterial properties of Malaysian tualang honey against wound and enteric microorganisms in comparison to manuka honey. BMC Complement. Altern. Med. 2009, 9, 34. [CrossRef]

92. Yusuf, W.N.W.; Mohammad, W.M.Z.W.; Gan, S.H.; Mustafa, M.; Aziz, C.B.A.; Sulaiman, S.A. Tualang honey ameliorates viral load, CD4 counts and improves quality of life in asymptomatic human immunodeficiency virus infected patients. J. Tradit. Complement. Med. 2019, 9, 249-256. [CrossRef]

93. Bulgasem, B.Y.; Lani, M.N.; Hassan, Z.; Yusoff, W.M.W.; Fnaish, S.G. Antifungal Activity of Lactic Acid Bacteria Strains Isolated from Natural Honey against Pathogenic Candida Species. Mycobiology 2016, 44, 302-309. [CrossRef] [PubMed]

94. Dixon, B. Bacteria can't resist honey. Lancet Infect. Dis. 2003, 3, 116. [CrossRef]

95. Hussein, S.Z.; Yusoff, K.M.; Makpol, S.; Yusof, Y.A.M. Gelam Honey Inhibits the Production of Proinflammatory, Mediators NO, PGE2, TNF- $\alpha$, and IL-6 in Carrageenan-Induced Acute Paw Edema in Rats. Evid. Based Complement. Altern. Med. 2012, $2012,1-13$. [CrossRef] [PubMed]

96. Kassim, M.; Achoui, M.; Mansor, M.; Yusoff, K.M. The inhibitory effects of Gelam honey and its extracts on nitric oxide and prostaglandin E2 in inflammatory tissues. Fitoterapia 2010, 81, 1196-1201. [CrossRef]

97. Hussein, S.Z.; Yusoff, K.M.; Makpol, S.; Yusof, Y.A.M. Gelam Honey Attenuates Carrageenan-Induced Rat Paw Inflammation via NF-kB Pathway. PLoS ONE 2013, 8, e72365. [CrossRef]

98. Kassim, M.; Yusoff, K.M.; Ong, G.; Sekaran, S.; Yusof, M.Y.B.M.; Mansor, M. Gelam honey inhibits lipopolysaccharide-induced endotoxemia in rats through the induction of heme oxygenase- 1 and the inhibition of cytokines, nitric oxide, and high-mobility group protein B1. Fitoterapia 2012, 83, 1054-1059. [CrossRef]

99. Kassim, M.K.A.; Mansor, M.; Al-Abd, N.M.; Yusoff, K.M. Gelam Honey Has a Protective Effect against Lipopolysaccharide (LPS)-Induced Organ Failure. Int. J. Mol. Sci. 2012, 13, 6370-6381. [CrossRef]

100. Kassim, M.K.A.; Mansor, M.; Suhaimi, A.; Ong, G.; Yusoff, K.M. Gelam Honey Scavenges Peroxynitrite during the Immune Response. Int. J. Mol. Sci. 2012, 13, 12113-12129. [CrossRef]

101. Shamshuddin, N.S.S.; Zohdi, R.M. Gelam honey attenuates ovalbumin-induced airway inflammation in a mice model of allergic asthma. J. Tradit. Complement. Med. 2018, 8, 39-45. [CrossRef]

102. Kamaruzaman, N.A.; Sulaiman, S.A.; Kaur, G.; Yahaya, B.H. Inhalation of honey reduces airway inflammation and histopathological changes in a rabbit model of ovalbumin-induced chronic asthma. BMC Complement. Altern. Med. 2014, 14, 176. [CrossRef]

103. Sairazi, N.S.M.; Sirajudeen, K.N.S.; Mustapha, M.; Mummedy, S.; Asari, M.A.; Sulaiman, S.A. Tualang Honey Reduced Neuroinflammation and Caspase-3 Activity in Rat Brain after Kainic Acid-Induced Status Epilepticus. Evid. Based Complement. Altern. Med. 2018, 2018, 1-16. [CrossRef] [PubMed]

104. Asari, M.A.; Zulkaflee, M.H.; Sirajudeen, K.; Yusof, N.A.M.; Sairazi, N.S.M. Tualang honey and DHA-rich fish oil reduce the production of pro-inflammatory cytokines in the rat brain following exposure to chronic stress. J. Taibah Univ. Med. Sci. 2019, 14, 317-323. [CrossRef] [PubMed]

105. Ghazali, W.S.W.; Romli, A.C.; Mohamed, M. Effects of honey supplementation on inflammatory markers among chronic smokers: A randomized controlled trial. BMC Complement. Altern. Med. 2017, 17, 175. [CrossRef] [PubMed]

106. Ranneh, Y.; Akim, A.M.; Ab Hamid, H.; Khaza'Ai, H.; Fadel, A.; Mahmoud, A.M. Stingless bee honey protects against lipopolysaccharide induced-chronic subclinical systemic inflammation and oxidative stress by modulating Nrf2, NF- $\mathrm{kB}$ and p38 MAPK. Nutr. Metab. 2019, 16, 1-17. [CrossRef] [PubMed] 
107. Erejuwa, O.; Sulaiman, S.A.; Wahab, M.; Sirajudeen, K.N.S.; Md Salleh, S.; Gurtu, S. Hepatoprotective effect of Tualang honey supplementation in streptozotocin-induced diabetic rats. Int. J. Appl. Res. Nat. Prod. 2012, 4, 37-41.

108. Erejuwa, O.O. Glibenclamide or Metformin Combined with Honey Improves Glycemic Control in Streptozotocin-Induced Diabetic Rats. Int. J. Biol. Sci. 2011, 7, 244-252. [CrossRef]

109. Rashid, M.R.; Aripin, K.N.N.; Mohideen, F.B.S.; Baharom, N.; Omar, K.; Taujuddin, N.M.S.M.; Yusof, H.H.M.; Addnan, F.H. The Effect of Kelulut Honey on Fasting Blood Glucose and Metabolic Parameters in Patients with Impaired Fasting Glucose. J. Nutr. Metab. 2019, 2019, 1-7. [CrossRef]

110. Robert, S.D.; Ismail, A.A. Two varieties of honey that are available in Malaysia gave intermediate glycemic index values when tested among healthy individuals. Biomed. Pap. 2009, 153, 145-147. [CrossRef]

111. Hussain, N.H.N.; Sulaiman, S.A.; Hassan, I.I.; Kadir, A.A.; Nor, N.M.; Ismail, S.B.; Yaacob, L.H.; Zakaria, R.; Shafie, N.S.; Haron, J.; et al. Randomized Controlled Trial on the Effects of Tualang Honey and Hormonal Replacement Therapy (HRT) on Cardiovascular Risk Factors, Hormonal Profiles and Bone Density Among Postmenopausal Women: A Pilot Study. J. Food Res. 2012, 1, 171-188. [CrossRef]

112. Ab Wahab, S.Z.; Hussain, N.H.N.; Zakaria, R.; Kadir, A.A.; Mohamed, N.; Tohit, N.M.; Norhayati, M.N.; Hassan, I.I. Long-term effects of honey on cardiovascular parameters and anthropometric measurements of postmenopausal women. Complement. Ther. Med. 2018, 41, 154-160. [CrossRef]

113. Lin, T.S.; Yahaya, M.F.; Arshad, N. Ain Stingless Bee Honey Reduces Anxiety and Improves Memory of the Metabolic Diseaseinduced Rats. CNS Neurol. Disord. Drug Targets 2020, 19, 115-126. [CrossRef]

114. Erejuwa, O.O.; Nwobodo, N.N.; Akpan, J.L.; Okorie, U.A.; Ezeonu, C.T.; Ezeokpo, B.C.; Nwadike, K.I.; Erhiano, E.; Abdul Wahab, M.S.; Sulaiman, S.A. Nigerian Honey Ameliorates Hyperglycemia and Dyslipidemia in Alloxan-Induced Diabetic Rats. Nutrients 2016, 8, 95. [CrossRef] [PubMed]

115. Yaghoobi, N.; Al-Waili, N.; Ghayour-Mobarhan, M.; Parizadeh, S.M.R.; Abasalti, Z.; Esmaeili, H.; Kazemi-Bajestani, S.M.R.; Aghasizadeh, R.; Saloom, K.Y.; Ferns, G.A.A. Natural Honey and Cardiovascular Risk Factors; Effects on Blood Glucose, Cholesterol, Triacylglycerole, CRP, and Body Weight Compared with Sucrose. Sci. World J. 2008, 8, 463-469. [CrossRef] [PubMed]

116. Bahrami, M.; Ataie-Jafari, A.; Hosseini, S.; Foruzanfar, M.H.; Rahmani, M.; Pajouhi, M. Effects of natural honey consumption in diabetic patients: An 8-week randomized clinical trial. Int. J. Food Sci. Nutr. 2009, 60, 618-626. [CrossRef] [PubMed]

117. Rafie, A.Z.M.; Syahir, A.; Ahmad, W.A.N.W.; Mustafa, M.Z.; Mariatulqabtiah, A.R. Supplementation of Stingless Bee Honey from Heterotrigona itama Improves Antiobesity Parameters in High-Fat Diet Induced Obese Rat Model. Evid. Based Complement. Altern. Med. 2018, 2018, 6371582. [CrossRef]

118. Samat, S.; Enchang, F.K.; Hussein, F.N.; Ismail, W.I.W. Four-Week Consumption of Malaysian Honey Reduces Excess Weight Gain and Improves Obesity-Related Parameters in High Fat Diet Induced Obese Rats. Evid. Based Complement. Altern. Med. 2017, 2017, 1342150. [CrossRef] [PubMed]

119. Ramli, N.Z.; Chin, K.-Y.; Zarkasi, K.A.; Ahmad, F. The Beneficial Effects of Stingless Bee Honey from Heterotrigona itama against Metabolic Changes in Rats Fed with High-Carbohydrate and High-Fat Diet. Int. J. Environ. Res. Public Health 2019, 16, 4987. [CrossRef]

120. Kuropatnicki, A.K.; Kłósek, M.; Kucharzewski, M. Honey as medicine: Historical perspectives. J. Apic. Res. 2018, 57, 113-118. [CrossRef]

121. Saikaly, S.K.; Litaiem, N. Honey and Wound Healing: An Update. Am. J. Clin. Dermatol. 2017, 18, 237-251. [CrossRef]

122. Al-Waili, N.S.; Salom, K.; Al-Ghamdi, A.A. Honey for Wound Healing, Ulcers, and Burns; Data Supporting Its Use in Clinical Practice. Sci. World J. 2011, 11, 766-787. [CrossRef]

123. Khoo, Y.-T.; Halim, A.S.; Singh, K.-K.B.; Mohamad, N.-A. Wound contraction effects and antibacterial properties of Tualang honey on full-thickness burn wounds in rats in comparison to hydrofibre. BMC Complement. Altern. Med. 2010, 10, 48. [CrossRef] [PubMed]

124. Halim, A.S.; Singh, K.K.B.; Sukur, S.M. Evaluations of bacterial contaminated full thickness burn wound healing in Sprague Dawley rats Treated with Tualang honey. Indian J. Plast. Surg. 2011, 44, 112-117. [CrossRef] [PubMed]

125. Aznan, M.I.; Khan, O.H.; Unar, A.O.; Sharif, S.E.T.; Khan, A.H.; Aziz, S.H.S.A.; Zakaria, A.D. Effect of Tualang honey on the anastomotic wound healing in large bowel anastomosis in rats-A randomized controlled trial. BMC Complement. Altern. Med. 2016, 16, 28. [CrossRef] [PubMed]

126. Lazim, N.M.; Abdullah, B.; Salim, R. The effect of Tualang honey in enhancing post tonsillectomy healing process. An open labelled prospective clinical trial. Int. J. Pediatr. Otorhinolaryngol. 2013, 77, 457-461. [CrossRef]

127. Tan, M.K.; Adli, D.S.H.; Tumiran, M.A.; Abdulla, M.A.; Yusoff, K.M. The Efficacy of Gelam Honey Dressing towards Excisional Wound Healing. Evid. Based Complement. Altern. Med. 2012, 2012, 1-6. [CrossRef]

128. Zohdi, R.M.; Zuki, A.B.; Yusof, N.; Noordin, M.M.; Abdullah, M.N.H. Gelam (Melaleuca spp.) Honey-Based Hydrogel as Burn Wound Dressing. Evid. Based Complement. Altern. Med. 2011, 2012, 1-7. [CrossRef]

129. Yusof, A.M.; Ghafar, N.A.; Kamarudin, T.A.; Chua, K.-H.; Azmi, M.F.; Ng, S.-L.; Yusof, Y.A.M. Gelam honey promotes ex vivo corneal fibroblasts wound healing. Cytotechnology 2019, 71, 1121-1135. [CrossRef]

130. Yusof, A.M.; Ghafar, N.A.; Kamarudin, T.A.; Chua, K.H.; Yusof, Y.A.M. Gelam honey potentiates ex vivo corneal keratocytes proliferation with desirable phenotype expression. BMC Complement. Altern. Med. 2016, 16, 76. [CrossRef] 
131. Azmi, M.F.; Ghafar, N.A.; Hamzah, J.C.; Luan, N.S.; Hui, C.K. The Potential of Gelam Honey in Promoting the Proliferative Phase of Corneal Reepithelialization. Wounds 2017, 29, 327-332.

132. Nordin, A.; Chowdhury, S.R.; Bin Saim, A.; Idrus, R.B.H. Effect of Kelulut Honey on the Cellular Dynamics of TGF $\beta$-Induced Epithelial to Mesenchymal Transition in Primary Human Keratinocytes. Int. J. Environ. Res. Public Health 2020, 17, 3229. [CrossRef]

133. Yazan, L.S.; Zainal, N.A.; Ali, R.M.; Zali, M.; Shyfiq, M.F.; Sze, O.Y.; Sim, T.Y.; Gopalsamy, B.; Ling, V.F.; Sapuan, S. Antiulcer Properties of Kelulut Honey against Ethanol-Induced Gastric Ulcer. Pertanika J. Sci. Technol. 2018, 26, 121-132.

134. Khalil, I.; Tanvir, E.M.; Afroz, R.; Sulaiman, S.A.; Gan, S.H. Cardioprotective Effects of Tualang Honey: Amelioration of Cholesterol and Cardiac Enzymes Levels. BioMed Res. Int. 2015, 2015, 1-8. [CrossRef] [PubMed]

135. Erejuwa, O.O.; Sulaiman, S.A.; Ab Wahab, M.S.; Sirajudeen, K.N.S.; Salleh, S.; Gurtu, S. Honey Supplementation in Spontaneously Hypertensive Rats Elicits Antihypertensive Effect via Amelioration of Renal Oxidative Stress. Oxidative Med. Cell. Longev. 2012, 2012, 1-14. [CrossRef] [PubMed]

136. Erejuwa, O.O.; Sulaiman, S.A.; Ab Wahab, M.S.; Sirajudeen, K.N.S.; Salleh, S.M.; Gurtu, S. Differential Responses to Blood Pressure and Oxidative Stress in Streptozotocin-Induced Diabetic Wistar-Kyoto Rats and Spontaneously Hypertensive Rats: Effects of Antioxidant (Honey) Treatment. Int. J. Mol. Sci. 2011, 12, 1888-1907. [CrossRef]

137. Devasvaran, K.; Tan, J.J.; Ng, C.T.; Fong, L.Y.; Yong, Y.K. Malaysian Tualang Honey Inhibits Hydrogen Peroxide-Induced Endothelial Hyperpermeability. Oxidative Med. Cell. Longev. 2019, 2019, 1202676. [CrossRef]

138. Zaid, S.S.M.; Sulaiman, S.A.; Sirajudeen, K.N.M.; Othman, N.H. The effects of tualang honey on female reproductive organs, tibia bone and hormonal profile in ovariectomised rats-Animal model for menopause. BMC Complement. Altern. Med. 2010, 10, 82. [CrossRef]

139. Zaid, S.S.M.; Sulaiman, S.A.; Othman, N.H.; Soelaiman, I.-N.; Shuid, A.N.; Mohamad, N.; Muhamad, N. Protective effects of Tualang honey on bone structure in experimental postmenopausal rats. Clinics 2012, 67, 779-784. [CrossRef]

140. Zaid, S.S.M.; Kassim, N.M.; Shatrah, O. Tualang Honey Protects against BPA-Induced Morphological Abnormalities and Disruption of ER $\alpha, \mathrm{ER} \beta$, and C3 mRNA and Protein Expressions in the Uterus of Rats. Evid.-Based Complement. Altern. Med. 2015, 2015, 1-18. [CrossRef]

141. Zaid, S.S.M.; Shatrah, O.; Kassim, N.M. Potential protective effect of Tualang honey on BPA-induced ovarian toxicity in prepubertal rat. BMC Complement. Altern. Med. 2014, 14, 509. [CrossRef]

142. Mohamed, M.; Sulaiman, S.A.; Jaafar, H.; Sirajudeen, K.N.S. Effect of different doses of Malaysian honey on reproductive parameters in adult male rats. Andrologia 2012, 44, 182-186. [CrossRef]

143. Mohamed, M.; Sulaiman, S.A.; Sirajudeen, K.N.S. Protective effect of honey against cigarette smoke induced-impaired sexual behavior and fertility of male rats. Toxicol. Ind. Health 2013, 29, 264-271. [CrossRef] [PubMed]

144. Haron, M.N.; Mohamed, M. Effect of honey on the reproductive system of male rat offspring exposed to prenatal restraint stress. Andrologia 2016, 48, 525-531. [CrossRef] [PubMed]

145. Ismail, S.B.; Bakar, M.B.; Hussain, N.H.N.; Norhayati, M.N.; Sulaiman, S.A.; Jaafar, H.; Draman, S.; Ramli, R.; Yusoff, W.Z.W. Comparison on the Effects and Safety of Tualang Honey and Tribestan in Sperm Parameters, Erectile Function, and Hormonal Profiles among Oligospermic Males. Evid. Based Complement. Altern. Med. 2014, 2014, 1-10. [CrossRef] [PubMed]

146. Azman, K.F.; Zakaria, R.; Ab Aziz, C.B.; Othman, Z. Tualang Honey Attenuates Noise Stress-Induced Memory Deficits in Aged Rats. Oxidative Med. Cell. Longev. 2016, 2016, 1-11. [CrossRef] [PubMed]

147. Azman, K.F.; Zakaria, R.; Abdaziz, C.; Othman, Z.; Al-Rahbi, B. Tualang honey improves memory performance and decreases depressive-like behavior in rats exposed to loud noise stress. Noise Health 2015, 17, 83-89. [CrossRef] [PubMed]

148. Sherwin, B.B. Estrogen and cognitive aging in women. Neuroscience 2006, 138, 1021-1026. [CrossRef]

149. Al-Rahbi, B.; Zakaria, R.; Othman, Z.; Hassan, A.; Ahmad, A.H. Enhancement of BDNF Concentration and Restoration of the Hypothalamic-Pituitary-Adrenal Axis Accompany Reduced Depressive-Like Behaviour in Stressed Ovariectomised Rats Treated with Either Tualang Honey or Estrogen. Sci. World J. 2014, 2014, 1-8. [CrossRef]

150. Al-Rahbi, B.; Zakaria, R.; Othman, Z.; Hassan, A.; Ismail, Z.I.M.; Muthuraju, S. Tualang honey supplement improves memory performance and hippocampal morphology in stressed ovariectomized rats. Acta Histochem. 2014, 116, 79-88. [CrossRef]

151. Al-Rahbi, B.; Zakaria, R.; Othman, Z.; Hassan, A.; Ahmad, A.H. Protective Effects of Tualang Honey against Oxidative Stress and Anxiety-Like Behaviour in Stressed Ovariectomized Rats. Int. Sch. Res. Not. 2014, 2014, 1-10. [CrossRef]

152. Othman, Z.; Shafin, N.; Zakaria, R.; Hussain, N.H.N.; Mohammad, W.M.Z.W. Improvement in immediate memory after 16 weeks of tualang honey (Agro Mas) supplement in healthy postmenopausal women. Menopause 2011, 18, 1219-1224. [CrossRef]

153. Sairazi, N.S.M.; Sirajudeen, K.N.S.; Asari, M.A.; Mummedy, S.; Muzaimi, M.; Sulaiman, S.A. Effect of tualang honey against KA-induced oxidative stress and neurodegeneration in the cortex of rats. BMC Complement. Altern. Med. 2017, 17, 1-12. [CrossRef]

154. Ab Aziz, C.B.; Suhaimi, S.Q.A.; Hasim, H.; Ahmad, A.H.; Long, I.; Zakaria, R. Effects of Tualang honey in modulating nociceptive responses at the spinal cord in offspring of prenatally stressed rats. J. Integr. Med. 2019, 17, 66-70. [CrossRef] [PubMed]

155. Ab Aziz, C.B.; Ismail, C.A.N.; Hussin, C.M.C.; Mohamed, M. The Antinociceptive Effects of Tualang Honey in Male SpragueDawley Rats: A Preliminary Study. J. Tradit. Complement. Med. 2014, 4, 298-302. [CrossRef] [PubMed]

156. Tang, S.P.; Salam, S.K.N.; Jaafar, H.; Gan, S.H.; Mustapha, M.; Sulaiman, S.A. Tualang Honey Protects the Rat Midbrain and Lung against Repeated Paraquat Exposure. Oxidative Med. Cell. Longev. 2017, 2017, 1-12. [CrossRef] [PubMed] 